\title{
The importance of policy design fit for effectiveness: a qualitative comparative analysis of policy integration in regional transport planning
}

\author{
Marijn T. van Geet ${ }^{1} \cdot$ Stefan Verweij $^{1} \cdot$ Tim Busscher $^{1} \cdot$ Jos Arts $^{1}$
}

Accepted: 5 June 2021 / Published online: 16 June 2021

(c) The Author(s) 2021

\begin{abstract}
Policy design has returned as a central topic in public policy research. An important area of policy design study deals with effectively attaining desired policy outcomes by aligning goals and means to achieve policy design fit. So far, only a few empirical studies have explored the relationship between policy design fit and effectiveness. In this paper, we adopt the multilevel framework for policy design to determine which conditions of policy design fit-i.e., goal coherence, means consistency, and congruence of goals and means across policy levels-are necessary and/or sufficient for policy design effectiveness in the context of policy integration. To this end, we performed a qualitative comparative analysis of Dutch regional transport planning including all twelve provinces. Outcomes show no condition is necessary and two combinations of conditions are sufficient for effectiveness. The first sufficient combination confirms what the literature suggests, namely that policy design fit results in policy design effectiveness. The second indicates that the combination goal incoherence and incongruence of goals and means is sufficient for policy design effectiveness. An in-depth interpretation of this counterintuitive result leads to the conclusion that for achieving policy integration the supportive relationship between policy design fit and policy design effectiveness is less straightforward as theory suggests. Instead, results indicate there are varying degrees of coherence, consistency, and congruence that affect effectiveness in different ways. Furthermore, outcomes reveal that under specific circumstances a policy design may be effective in promoting desired policy integration even if it is incoherent, inconsistent, and/or incongruent.
\end{abstract}

Keywords Policy design $\cdot$ Coherence $\cdot$ Consistency $\cdot$ Congruence $\cdot$ Policy integration · Transport planning

Marijn T. van Geet

m.t.van.geet@rug.nl

1 Faculty of Spatial Sciences, University of Groningen, Landleven 1, 9700 AV Groningen,

The Netherlands 


\section{Introduction}

How to develop policy designs that effectively address policy problems has been an ongoing topic of research for decades. A policy design is generally understood as a mix of interrelating goals and means that governments employ to give effect to their policies (Howlett \& Rayner, 2013; Howlett, 2014a). Even though policy design thinking has expanded considerably over the years, a key component has always focused on bringing about intended policy outcomes by consciously matching goals and means (Howlett \& Mukherjee, 2018a) because a good fit between goals and mean is said to minimize incompatibilities and exploit synergies, so as to improve policy design effectiveness (Rayner et al., 2017). In this setting, policy design fit is considered to be the sum of coherence of goals, consistency of means, and congruence of goals and means (Van Geet et al., 2019a, 2019b). Contemporary studies on policy design often present these elements-coherence, consistency, and congruence - as the criteria that determine policy design effectiveness (e.g., Howlett \& Rayner, 2013, 2018; Kern \& Howlett, 2009).

To further mature as a field, policy design studies would benefit from methodological innovations and a stronger emphasis on the application and operationalization of the field's theoretical principles (see e.g., Rogge et al., 2017; Schmidt \& Sewerin, 2018). This also applies to the relationship between policy design fit and effectiveness which, to date, has undergone limited empirical testing (Rogge \& Schleich, 2018). Consequently, the evidence for the positive relationship between policy design fit and policy design effectiveness has been predominantly of a theoretical nature (e.g., Howlett, 2009; Howlett \& Rayner, 2013, 2018; Rayner et al., 2017). Not only have existing empirical studies hardly addressed all three conditions of policy design fit together, but they also present different findings of the importance of design coherence, consistency, and congruence for achieving desired outcomes (see Kern et al., 2017; Kern \& Howlett, 2009; Reichardt \& Rogge, 2016; Rogge \& Schleich, 2018). A systematic empirical analysis, including all three conditions, of how coherence, consistency, and congruence-i.e., policy design fit-contribute to policy design effectiveness is lacking. This article aims to bridge this research gap by investigating to what extent policy design fit is needed for policy design effectiveness.

Understanding the relationship between policy design fit and design effectiveness is especially relevant in moving toward more comprehensive policy integration. Recently, there is increased interest in linking policy design thinking and policy integration research (Peters, 2018). The purposive nature of policy design can help to achieve the increased integration between policy areas and levels of government that is needed to address crosscutting policy problems (Candel \& Biesbroek, 2016; Cejudo \& Michel, 2017). Several scholars have already highlighted that certain policy instruments can help to address policy issues that span across policy fields and levels of government (Jordan et al., 2005). However, few policy design studies have given this consideration (Peters, 2018). So far, it has remained unclear whether and how aligning policy goals and instruments help to effectively bring about desired policy integration. An earlier study by Van Geet et al. (2019b) did reveal that discrepancies in the degree of integration between policy goals and policy instruments give rise to policy design incoherence, inconsistency, and incongruence. It is, however, unclear to what extent these mismatches between policy design elements impede effective policy integration.

The current study addresses these research gaps and investigates whether all three attributes of policy design fit are required, or whether, for example, only coherence or a certain combination of attributes, is sufficient for effectively achieving desired policy integration. 
Our study focuses on the impact of policy design fit in the domain of transport planning, where the challenge of promoting policy integration has become particularly apparent. Over the course of decades, transport planning evolved from an unimodal approach, to a multimodal approach, to an integrated approach on land use and transport planning (Arts et al., 2016; Busscher et al., 2015; Heeres et al., 2012). While the field has progressed toward increased integration, governments are struggling to come up with effective policy designs to support current integrated ambitions on land use and transport (Van Geet et al., 2019a).

To achieve its objective, the current study applies Howlett's (2009) multilevel policy design framework to study policy integration in Dutch regional transport planning and adopts qualitative comparative analysis (QCA) methodology to analyze the policy designs of all 12 Dutch provinces. More specifically, this research design is adopted to investigate whether the coherence of goals, the consistency of means, and the congruence of goals and means - or combinations of these three attributes - are necessary and/or sufficient for effective policy integration. QCA was selected both for its systematic approach to case comparison and for its configurational nature (Gerrits \& Verweij, 2018; Rihoux \& Ragin, 2009), which means that it allows for analyzing the necessity and sufficiency of conditions or combinations of conditions for achieving certain outcomes. QCA is an appropriate method for studying policy designs and explaining policy outcomes (Rihoux et al., 2011). Even though QCA has been used in public policy studies (Rihoux et al., 2011) and planning studies (Verweij \& Trell, 2019) before, it offers a new methodological approach to examining the influence of policy design fit on policy design effectiveness.

\section{Theoretical framework}

\section{A multilevel approach to policy design}

The literature on policy design has come a long way. In its early stages, policy design thinking revolved around Tinbergen's (1952) notion that the most effective policy design consists of a 1-to-1 goal-means ratio, where one instrument fully addresses one policy goal (Knudson, 2008). Tinbergen himself acknowledged the difficulty of maintaining this 1-to-1 ratio because comprehensive policy goals will require a mix of policy instruments. Yet, it took some time for his policy design approach to develop into the more comprehensive thinking that a policy design should be understood as a mix of interrelated goals and instruments that are deployed throughout the policy process (Howlett \& Rayner, 2018; Howlett et al., 2015; Howlett, 2014a).

Key principles of current policy design thinking are captured by the nested model introduced by Howlett (2009), building on the work by Hall (1993) and Cashore and Howlett (2007), as visualized in Fig. 1. Since its introduction, this model has been incrementally developed and further established in a series of studies (Howlett \& Cashore, 2009; Howlett \& Rayner, 2013; Howlett \& Mukherjee, 2018b; Peters et al., 2018; Howlett, 2019). The model adopts a multilevel perspective on how mixes of policy goals and means are formed, based on the principle that higher levels of abstraction delineate and shape the features at the lower levels. The highest level of abstraction is the macro-level. This concerns the general mode of governance (e.g., corporatist, market, and network governance) that shapes policy deliberations and decision-making, as well as the preferred type of government regulation mechanisms (e.g., legal, financial, or communicative mechanisms) (Howlett, 2009, 


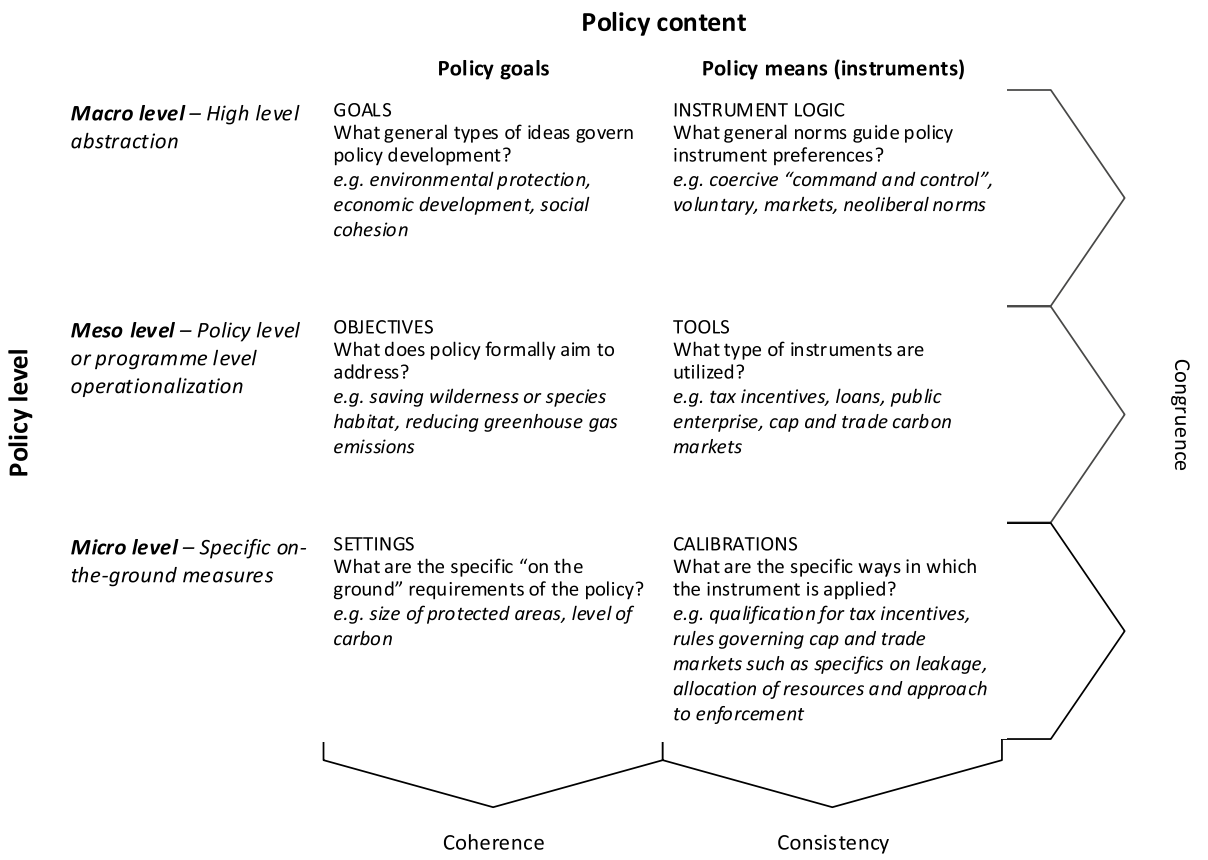

Fig. 1 Components of public policy in policy design and conditions for policy design fit. Based on: Cashore and Howlett (2007b), Howlett (2009), and Howlett (2018a)

2018a). Howlett (2018b) describes the macro-level as the contextual features that structure the policy formation and policy implementation practices of governments. The intermediate level of abstraction is the meso-level. This is referred to as the policy level and concerns the generic set of policy objectives of a certain policy sector, as well as the combination of policy instruments that are used throughout the policy process to attain these objectives (Howlett, 2018b). The decisions on policy design that are made on the meso-level set the boundaries for the design choices that can be made at the micro-level, which is the third and lowest level of abstraction. At the micro-level, policy design is operationalized and directly linked to goal attainment. Micro-level policy design is concerned with the delivery of policy outcomes. It is the level of the specific on-the-ground measures that are formed by detailed policy goal settings and specific instrument calibrations.

A key aspect that hallmarks current policy design thinking is the conscious effort to bring configurations of interrelating policy goals and instruments into alignment, so as to effectively achieve intended outcomes (Howlett et al., 2015). Multiple scholars have defined attributes to operationalize the alignment of design components. Examples include coordination, complementarity, coherence, consistency, and congruence (Bali \& Ramesh, 2018). Some of these concepts partly overlap, as their focus is on either of three possible relations; the alignment between goals, between means, or between goals and means. When it comes to the multilevel understanding of a policy design that is adopted here, the alignment across components is generally expressed as, the coherence of goals, the consistency of means, and the congruence of goals and means (Howlett, 2009; Howlett \& Rayner, 2013). This is shown in Fig. 1. More specifically, coherence is achieved when goals, objectives, and settings can be pursued at the same time without trade-offs (Kern \& Howlett, 2009). Rogge and Reichardt (2016) argued that the consistency of a policy design reflects 
how well instruments are aligned with each other and how well they contribute to achieving the same policy objective. Their study explained that consistency may range from the absence of contradictions between policy means to the existence of synergies between policy means. This is in line with Howlett and Rayner's (2013) view that the consistency of policy means is reflected by the 'ability of multiple policy tools to reinforce rather than undermine each other in the pursuit of goals' (p. 174). Congruence, finally, reflects the extent to which policy goals and means are mutually supportive and successful at working together to achieve corresponding goals (Kern \& Howlett, 2009). The sum of goal coherence, mean consistency, and congruence of goals and means, may be described as policy design fit (van Geet et al., 2019b).

Policy design fit is a dynamic concept; policy design components develop over time, through processes of layering, drift, conversion, replacement, and exhaustion (Kern \& Howlett, 2009; Rayner, et al., 2017; van Geet et al., 2019b). It is important to take into account these processes of change as they will impact the fit of policy design components (van Geet et al., 2019b). Cashore and Howlett (2007) provide useful insight on how processes of policy design change unfold between goals and means across different policy levels. They found dynamics to differ across the model's components goals, objectives, settings, instrument logic, tools, and calibrations, because they evolve irregularly at a varying tempo, depending on the institutional structures that are in place for each component. In general, it is assumed that the macro-level is characterized by long-lasting stability; at the meso-level instances of policy change will occur in a higher frequency; and the micro-level is most dynamic (Hall, 1993; Howlett, 2009).

\section{Attributes of policy design effectiveness}

Effectiveness is widely acknowledged to be the fundamental goal of any policy design and is receiving considerable attention from design scholars. This is not surprising as effectiveness is generally considered the foundation upon which additional goals-such as sustainability, public value, or justice-may be constructed (Bali et al., 2019; Howlett, 2018b; Mukherjee \& Bali, 2018; Mukherjee \& Howlett, 2018; Peters, 2018; Peters et al., 2018; Rogge \& Reichardt, 2016). Peters et al. (2018) even argued that effectiveness is why policymakers, either implicitly or explicitly, engage in policy design in the first place. The growing interest in policy design has encouraged scholars to identify a variety of attributes that, in complement to policy design fit, are considered to potentially affect policy design effectiveness. Within this rapidly growing body of literature, a differentiation can be made between effectiveness in terms of process - in which policy design is seen as a verb - and content-in which policy design is seen as a noun (Howlett \& Rayner, 2013; Peters et al., 2018). This study focuses on the effectiveness of a policy design as a verb-i.e., the extent to which the technical specifications of a policy design are successful in attaining desired outcomes.

In recent years discussions on policy design effectiveness (as a noun that is) have converged to explore a variety of attributes that go beyond the traditional focus of matching goals and instruments. Schmidt and Sewerin (2018), for example, pose that policy designs with a higher intensity-i.e., the amount of resources or activity that is invested or allocated to a specific policy instrument-and a higher balance-i.e., the variety of instrument types within a design—will be more effective. Additionally, Thomann (2018) highlighted that explicitness in the calibration of a policy instrument-i.e., the extent to which desired behavior is encouraged by attributing positive or native valence to certain 
actions - in part accounts for its effectiveness. Furthermore, Mukherjee and Bali (2019) argue that the capacity-i.e., the range of analytical, operational, and political skills-a government has available will determine its ability to successfully put instruments to use for achieving desired outcomes. Finally, both Peters et al. (2018) and Capano and Howlett (2019) describe the goodness-of-fit attribute, which holds that the calibration of an instrument needs to be responsive to the context in which it is deployed. Despite these valuable theoretical contributions, there is scant empirical evidence on the interrelationship between these attributes and design effectiveness. Filling this research gap is an important next step for bridging the growing gap between policy design theory and practice. Increasing our understanding of the relationship between policy design fit and effectiveness is an important first step to be made as this may be considered the foundation of current design thinking and still plays a leading role in contemporary policy design theory (e.g., Howlett \& Mukherjee, 2018; Howlett \& Rayner, 2013, 2018; Howlett, 2009, 2018b).

The limited number of conducted empirical studies on the relationship between policy design fit and effectiveness has been confined to a single-level focus on policy design and reveal different outcomes based on divergent research approaches. For example, Kern and Howlett's (2009) single-case study describes how discrepancies in the development of policy goals and means over time resulted in sub-optimal outcomes, as a result of instrumental inconsistency as well as growing incongruence between goals and means. However, they did not explain how incongruence and inconsistency negatively influenced policy design effectiveness. Similarly, Kern et al. (2017) study on design dynamics implied that consistency and coherence may encourage goal attainment. However, they have not supported this claim by analyzing achieved policy outcomes. Rogge and Schleich's (2018) pioneering explorative quantitative study tested how the perception of German companies $(n=390)$ regarding the coherence, consistency, and congruence of a policy design was associated with the policy outcome of low-carbon innovation. This study found only weak support for consistency and congruence, while coherence was not significantly contributing to the achievement of intended outcomes. Furthermore, Reichardt and Rogge (2016) conducted a multiple-company case study $(n=6)$ and found that stable and coherent long-term policy goals, in combination with a consistent mix of policy instruments that were congruent with the long-term goals, led to successful corporate innovation in the offshore wind energy in Germany. Taken together, these empirical studies provide initial evidence that design coherence, consistency, and congruence may benefit policy design effectiveness. However, a systematic assessment of the relationship between policy design fit and effectiveness based on the multilevel understanding of policy design is still missing.

\section{Operationalizing policy design effectiveness}

When it comes to determining the effectiveness of a policy design, the current body on policy design literature broadly provides the conformance and performance approaches as the two main alternatives. The first, which is also the most widely described, regards effectiveness as the degree to which a policy design achieves intended outcomes (e.g., Howlett $\&$ Rayner, 2018). In this approach, effectiveness is determined by comparing policy intentions to outcomes. The conformance approach to effectiveness is in line with the purposive understanding of policy design as a systematic effort to link appropriate means to attain predefined goals. Del Río (2014) argues that, despite the straightforward nature of this conformance-perspective, design effectiveness remains a multifaceted notion; any criteria for measuring effectiveness are to be specifically defined for each individual policy design 
to 'include different criteria and policy goals which are relevant' (Del Río, 2014, p. 269). Multiple scholars highlighted that policy monitors and policy evaluations may be used for assessing this type of design effectiveness (Del Río, 2014; Doremus, 2003; Howlett, 2018c; Peters et al., 2018). Alternatively, the performance approach to policy design effectiveness, which was introduced by Peters et al. (2018), focuses on how a policy design performs as a 'frame for action [...] through which problem, process, and result are collectively defined and accepted' (Peters et al., 2018, p. 14). The performance approach is more geared toward the effectuality of policy processes. From this perspective, effectiveness is determined by analyzing the policy processes that follow the employment of a policy design to determine whether a policy design effectively supports policy actors in making sense of policy problems and addressing them. To date, this performance approach to design effectiveness is still in its infancy; the literature provides limited leads to develop a robust method for performance assessment. Thus, this study will adopt a conformance understanding of policy design effectiveness that revolves around comparing policy goals to policy outcomes.

\section{Research design}

This paper aims to determine whether all three conditions of policy design fit, or whether a single condition or a combination of two conditions are sufficient to ensure policy design effectiveness. To this end, we apply qualitative comparative analysis (QCA). This is a settheoretic method for analyzing the necessary and sufficient conditions (or combinations of conditions) that explain a certain outcome of interest (Schneider \& Wagemann, 2012). As such, it allows testing conditions for effective policy design, while maintaining a qualitative understanding of the specifics of the individual cases from which results are derived. To be able to maintain this in-depth qualitative understanding, QCA works best for an intermediate number of cases. In QCA, studying a small or intermediate number of 12 cases is common (see e.g., Rihoux et al., 2013; Verweij \& Trell, 2019). The 12 cases are naturally sufficient for this study because they constitute the entire population of Dutch provinces. This section goes into the design and execution of the qualitative comparative analysis methodology.

\section{Adopting policy design thinking to study policy integration}

Policy design fit-i.e., coherence, consistency and, congruence-is a multi-faceted concept; its operationalization and assessment will depend on the 'specific job at hand' (Howlett, 2014b). When it comes to the job of achieving policy integration, work by Candel and Biesbroek (2016) provides a base for operationalizing these policy design conditions. More generally, policy integration is understood here as a strategy to overcome the fragmented organization of the public sector in order to address problems that cross established administrative and jurisdictional boundaries (see e.g., Cejudo \& Michel, 2017; Trein et al., 2019). Candel and Biesbroek (2016) put forward policy integration as an ongoing process. They discern between goals and instruments as two of the dimensions on which these processes on integration take place that vary on a spectrum from a low to a high degree of integration. They argue that integration processes often show discrepancies or a-synchronicity across dimensions and that consequently, goals and means may be of a different degree, or level, of integration. For this study, we use the synchronicity of the integration process across goals and means as a measure for policy design fit. 
To determine the level of integration of goals and instruments, Candel and Biesbroek (2016) have formulated specific criteria. On the dimension of policy goals, the degree of integration is dependent on two aspects. First, the range of policies, both between as within subsystems that collectively address the same problem (e.g., domains of transport, energy, and maritime all addressing climate change) and second, the extent to which different subsystems embed their policy goals in an overarching strategy directed at solving a collective problem. Additionally, the degree of integration on the dimension of policy means is reflected by three aspects. First, the diversity of instruments that are deployed and support each other in addressing a collective goal. Second, the range of instruments in place that structure interaction and coordinate policy action across administrative boundaries to achieve collective, overarching goals (e.g., interdepartmental working groups, overarching plans, overarching funding programs). Third, the extent to which a mix of cross-subsystem instruments is adopted, tailored to meet an overarching policy goal.

Over time, transport planning has incrementally evolved toward an advanced level of integration—see Fig. 2 (Curtis \& James, 2004; Heeres, 2017; Van Geet et al., 2019a). Traditionally, transport planning was characterized by a sectoral unimodal approach in which sectoral specialization resulted in the segmented planning of roads, railways, and waterways (Busscher et al., 2015; Owens, 1995). However, as the awareness increased of the interrelationships between different modes of transport and the interactions between land use and transport, multimodal, and integrated land use and transport planning approaches were developed (Hull, 2010; Potter \& Skinner, 2000). A multimodal approach focuses on the entire transport system and regards the different modes of transport and infrastructure networks as functioning as an integrated whole (Arts et al., 2014; Heeres et al., 2012; Hull, 2005). Integrated land use and transport planning goes one step further and also considers the reciprocal relationship between the multimodal transport system and land use (Hull, 2010; Wegener \& Fürst, 1999). It focuses on 'people' and 'places,' by acknowledging that travel is a means to engage in activities such as meeting family, working, and shopping (UN-Habitat, 2013) and that transport infrastructure connects different spatial functions where these activities take place (Heeres et al., 2012, 2016). The latter approach combines transport planning measures (e.g., investment in infrastructure networks) and land use planning measures (e.g., mixed-use planning, urban density, proximity, and distance to public transport) to achieve broad policy goals, such as improving accessibility (Hull, 2010; Straatemeier, 2019; Van Wee et al., 2013) or sustainable mobility (Banister, 2008; Bertolini et al., 2005).

Collectively, these studies on policy integration and transport planning provide a foundation for operationalizing this QCA's four policy design attributes. The three conditioning attributes are assessed based on the synchronicity of the policy design in terms of integration. Table 1 shows how each component may be scored as unimodal, multimodal, or integrated land use and transport. Depending on synchronicity that is consequently observed between the policy design's components, policy design coherence, consistency

Unimodal planning - sectoral specialization
Multimodal planning - Intra-sectoral integration on transport system level
Integrated land use and transport planning - Intersectoral integration of land use and transport

Fig. 2 Three approaches to transport planning positioned on a spectrum from a low degree to a high degree of integration 


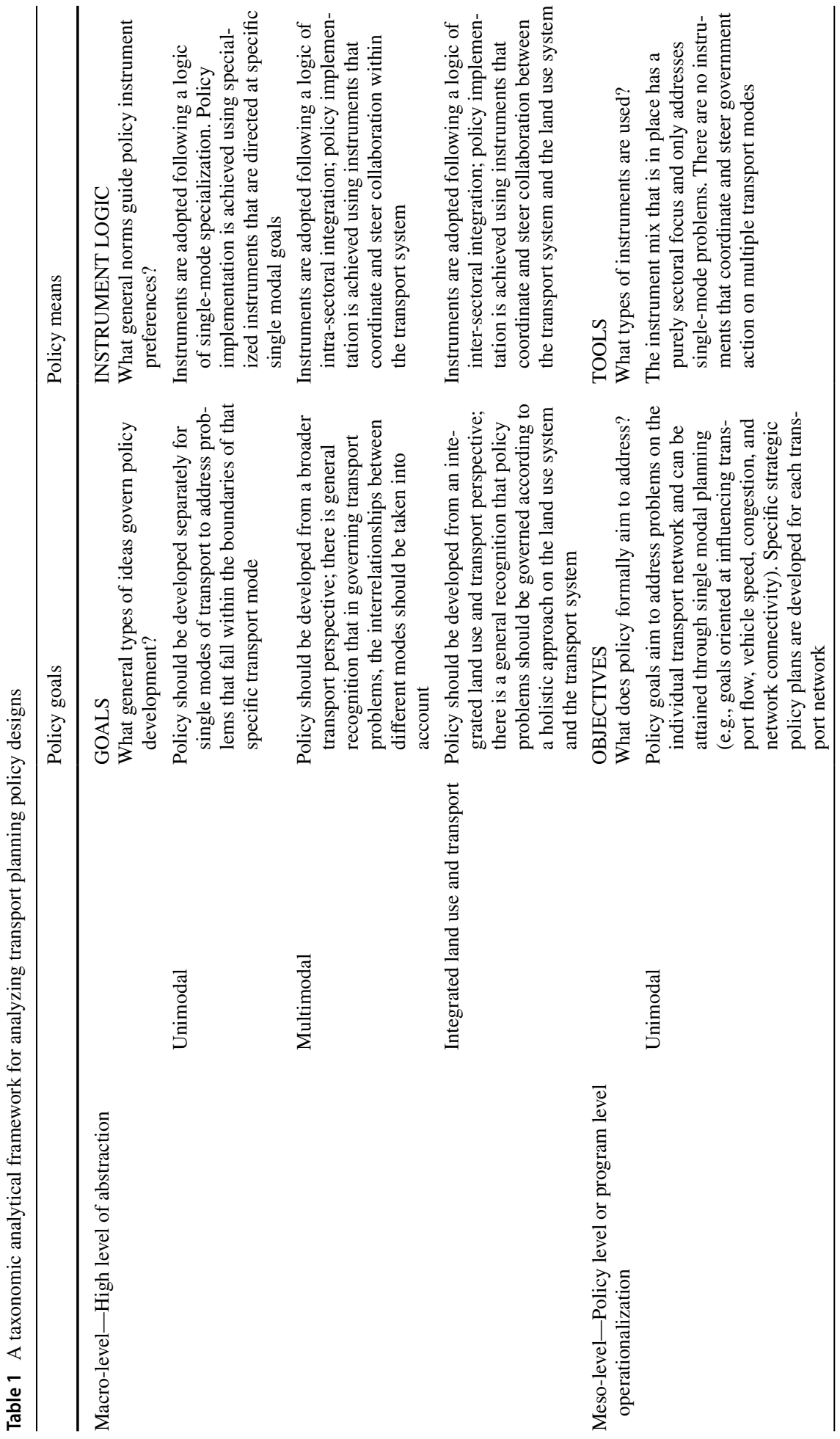




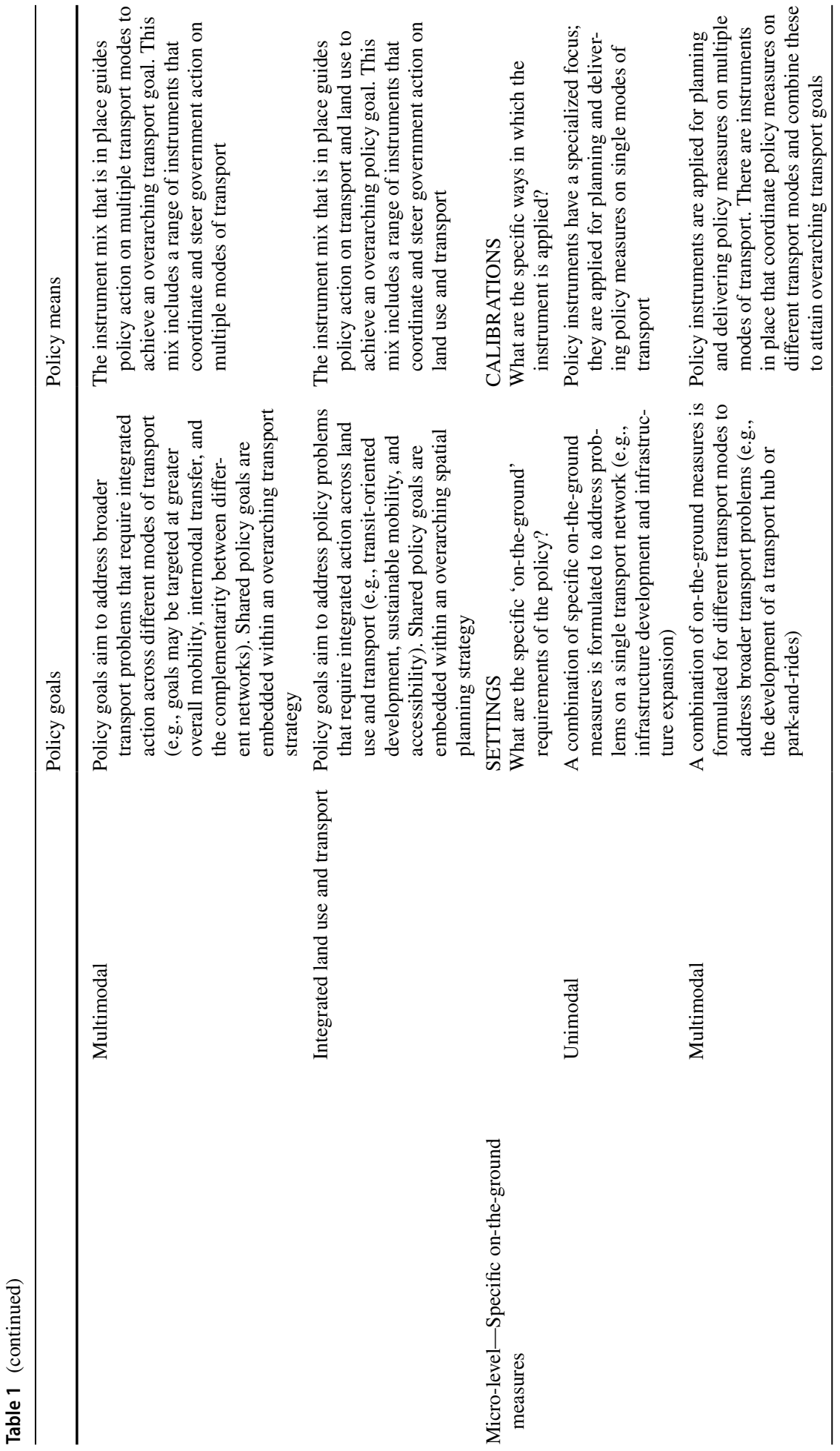




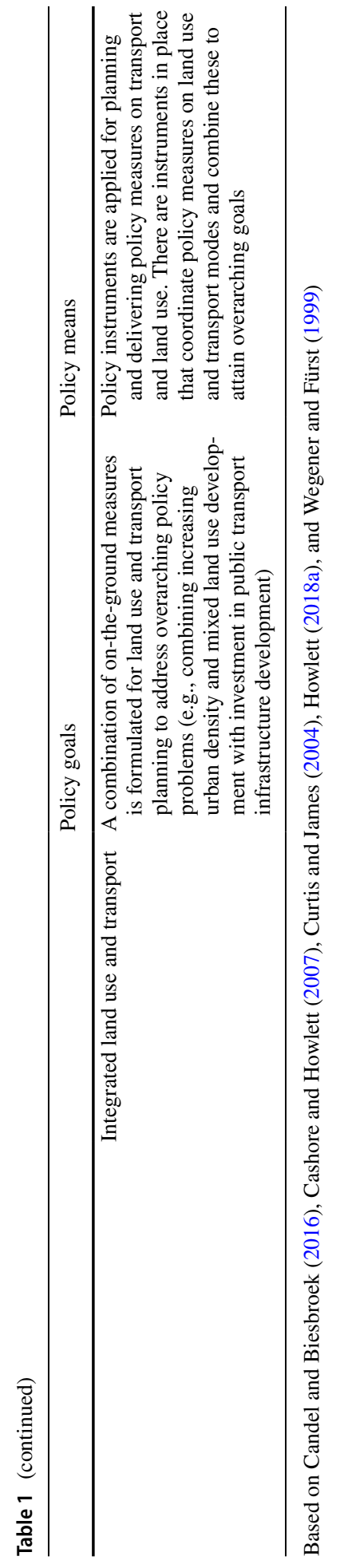


and congruence will be determined. The outcome attribute will be assessed on the extent to which policy outcomes correspond to the desired degree of integration. This is done, in line with conformance thinking, by comparing the level of integration of meso-level goals to the level of integration of the achieved policy outcomes. This intermediate-level is the key level when it comes to determining effectiveness as these are the objectives you hope to achieve in formulating specific on-the-ground measures.

\section{Unit of analysis}

The transport planning policy design is the unit of analysis for each of the twelve cases. Each of the designs included in this study was adopted between 2003 and 2009. The effectiveness of each design was assessed from its adoption until 2020 - so over the course of at least ten years. Data were collected in the form of provincial policy documents, provincial websites, internet archives, and online policy monitors. A total of 193 sources were collected and coded in ATLAS.ti. Table 2 provides an overview of the documents and websites. The reference list is given in the Appendix.

\section{Calibration and the data matrix}

As part of the QCA, the collected data were calibrated following the guidelines of Basurto and Speer (2012), De Block and Vis (2018), and Gerrits and Verweij (2018). During the calibration, membership scores are defined for each case on every 'set.' In QCA, each condition and the outcome is understood as a 'set.' Our analysis includes four sets: the conditions coherence, consistency, and congruence, and the outcome was effectiveness. Calibration involves the transformation of the qualitative case information (in this case the coded documents for the twelve transport planning policy designs) into quantitative setmembership scores (Gerrits \& Verweij, 2018). We based our calibration choices on the analytical framework and operationalization presented above. An extensive overview of the data calibration can be found as supplementary material.

The data were calibrated through systematic document coding in ATLAS.ti and followed three steps for every case. The first step involved coding the data in line with the policy design components outlined in Fig. 1. The main long-term strategic transport plan of every province was retrieved and was used to identify the policy goals and policy means. These data were complemented with additional material regarding the policy means that were described in the strategic plan (see Table 2). This provided an overview of the macro-, meso-, and micro-level transport planning policy goals and means of each of the provinces. In a second step, using the criteria listed in Table 1, the degree of integration for each of the design components was assessed for each province. In other words, each of the design components was qualified as either unimodal, multimodal, or integrated land use and transport. Additionally, the policy outcomes were reviewed to determine whether the policy design was effective. Policy design effectiveness was scored by triangulating evidence from Provincial Annual Reports and from material on monitoring and evaluation. Table 2 provides an overview of the material that was used in the process of data calibration, and Table 3 presents the output.

The third step was quantifying the case data. This quantification is necessary for the QCA. The calibration rules are provided in Table 4. We used a crisp-set calibration (i.e., binary quantification) because of the highly qualitative nature of the data and because of the lack of precise scales in the literature for differentiating degrees of policy design 


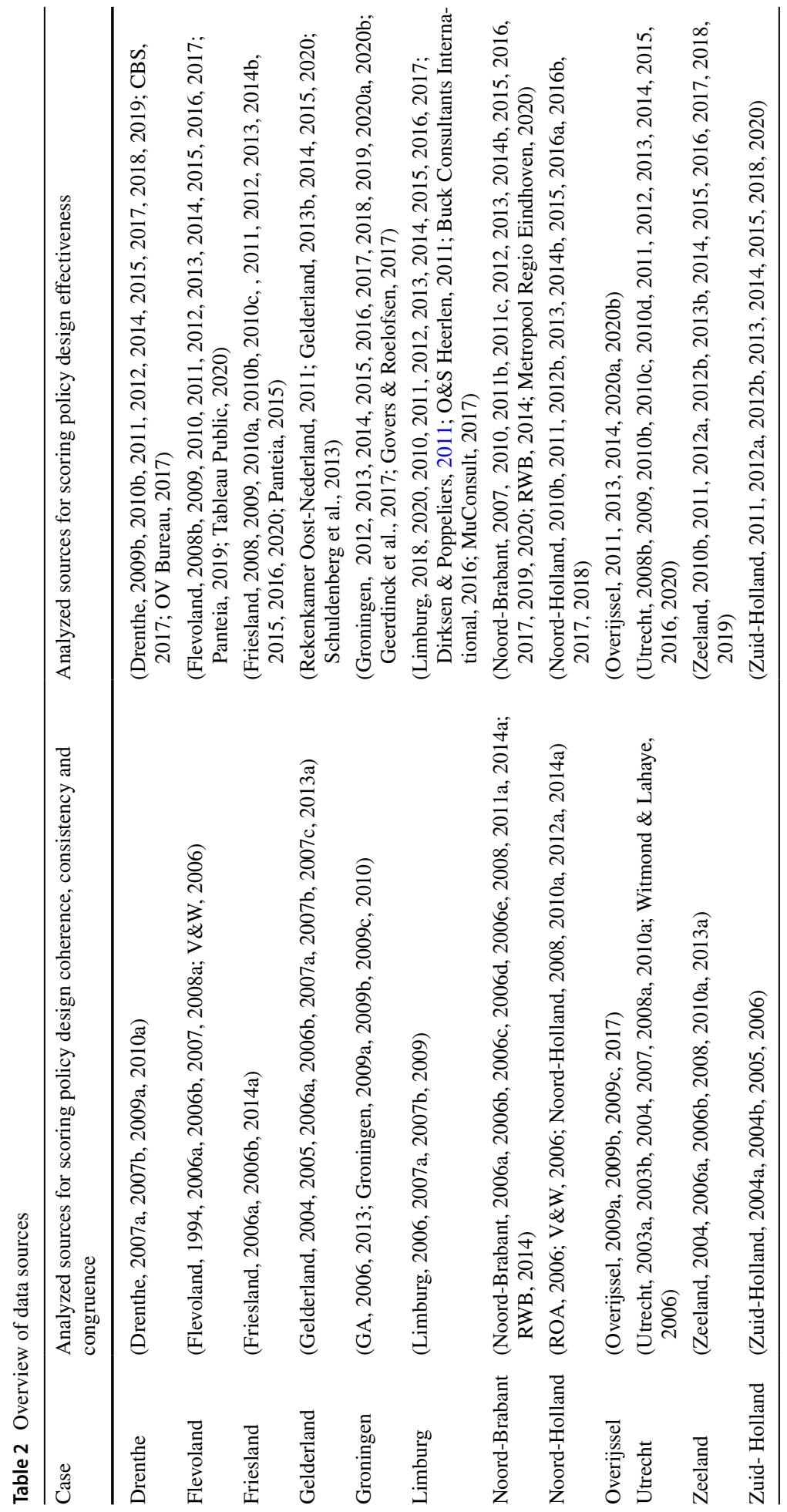




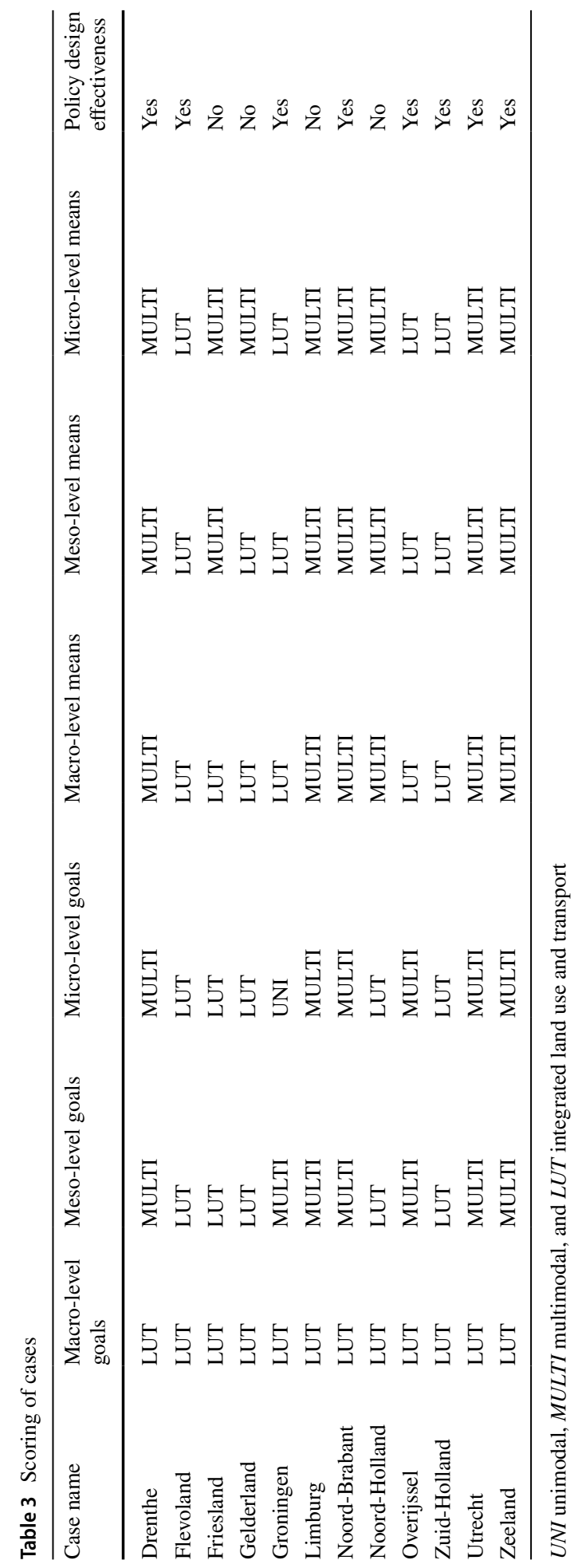




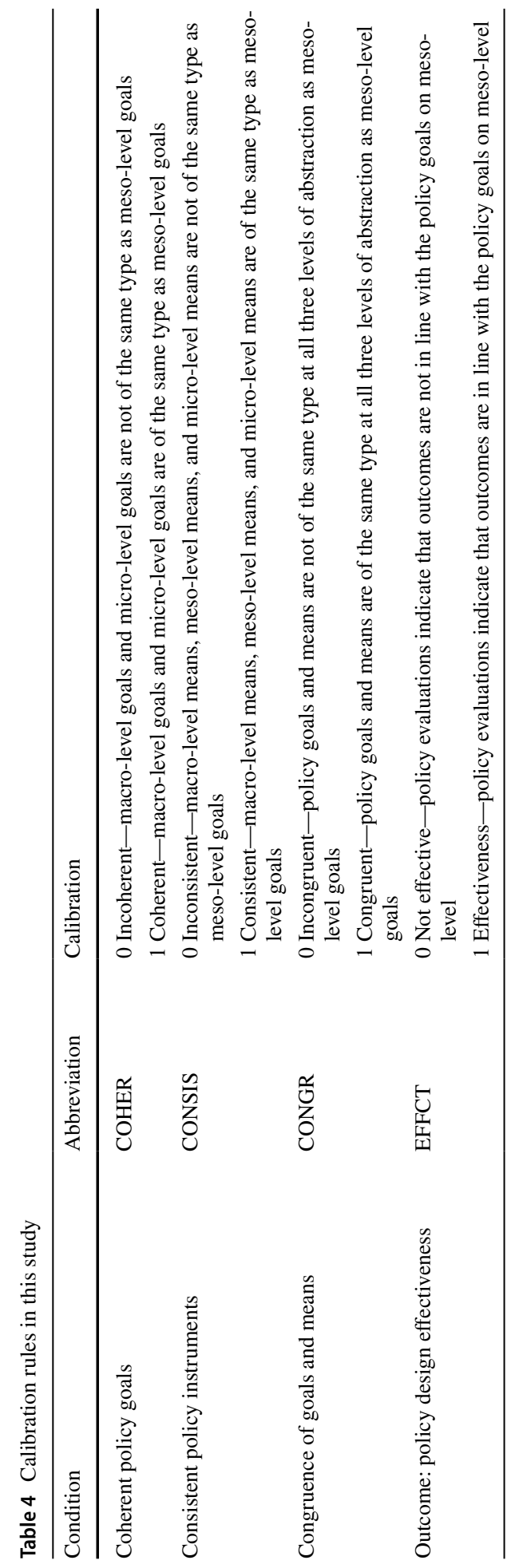


Table 5 Calibrated data matrix

\begin{tabular}{|c|c|c|c|c|}
\hline \multirow[t]{2}{*}{ Case } & \multicolumn{2}{|c|}{ Conditions } & \multicolumn{2}{|l|}{ Outcome } \\
\hline & COHER & CONSIS & CONGR & EFFCT \\
\hline Zuid-Holland & 1 & 1 & 1 & 1 \\
\hline Flevoland & 1 & 1 & 1 & 1 \\
\hline Noord-Holland & 1 & 0 & 0 & 0 \\
\hline Friesland & 1 & 0 & 0 & 0 \\
\hline Gelderland & 1 & 0 & 0 & 0 \\
\hline Drenthe & 0 & 1 & 0 & 1 \\
\hline Noord-Brabant & 0 & 1 & 0 & 1 \\
\hline Utrecht & 0 & 1 & 0 & 1 \\
\hline Zeeland & 0 & 1 & 0 & 1 \\
\hline Limburg & 0 & 1 & 0 & 0 \\
\hline Overijssel & 0 & 0 & 0 & 1 \\
\hline Groningen & 0 & 0 & 0 & 1 \\
\hline
\end{tabular}

\section{Noord-Brabant}

Policy design elements

Level of abstraction

Macro level-governance mode

Integrated land use and transport

Goals

Means

Multimodal

Meso level-policy regimes

Multimodal

Multimodal

Micro level - operational plans

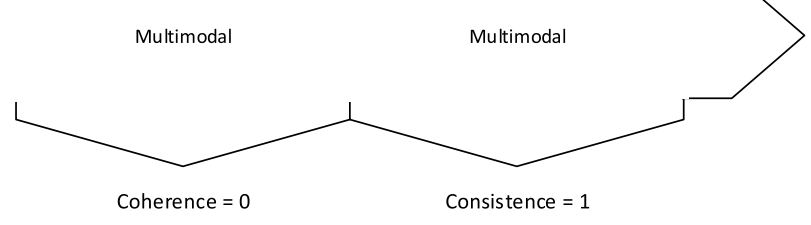

Fig. 3 Scores of the policy design components and calibration for the conditions coherence, consistency, and congruence for Noord-Brabant

coherence, consistency, and congruence. By applying the calibration rules in Table 4 to the case scorings in Table 3, the so-called calibrated data matrix was constructed. The calibrated data matrix is provided in Table 5.

Figure 3 illustrates how the application of the calibration rules resulted in coherence, consistency, and congruence scores in the case of Noord-Brabant. This figure shows that the policy design of Noord-Brabant is incoherent since the macro-level goals show a different degree of integration than the meso- and micro-level goals. In contrast, the policy design is consistent as macro-, meso-, and micro-level means all show the same degree of integration. Furthermore, the design is incongruent as the macro-level goals 
and macro-level means show a different degree of integration. Finally, our analysis of the policy outcomes found this policy design to be effective.

\section{Qualitative comparative analysis results}

The analysis was carried out using Charles Ragin and Sean Davey's Fuzzy-Set/Qualitative Comparative Analysis 3.0 software. First, a test for necessary conditions was performed. A condition is necessary when the outcome cannot be achieved without it (Gerrits \& Verweij, 2018). The results of the necessity analysis are presented in Table 6. A tilde sign indicates the absence of a condition; for example, COHER means incoherent. The consistency value in the second column of Table 6 reflects the degree to which the cases-the empirical evidence-support the claim that the set-theoretic relationship exists. The coverage value expresses the empirical importance of the relationship (ibid.). As no condition has a consistency value of 0.9 or higher, we find that no single condition is necessary for policy design effectiveness.

Subsequently, the sufficiency of the configurations was determined by using a truth table analysis. The truth table in Table 7 lists all the logically possible combinations of conditions and illustrates the cases that are covered by these combinations. Truth table analysis involves the pairwise comparison of configurations that agree on the outcome and differ for only one of the conditions. Four configurations had no cases and thus are not included in the analysis. One configuration (i.e., COHER $*$ CONSIS $* \sim$ CONGR) has a consistency below 0.75 and thus is not included in the analysis either (Gerrits \& Verweij, 2018; Ragin, 2009). In the end, three configurations were selected for the pairwise comparison. The analysis was specified to explain positive outcomes, i.e., policy design effectiveness. Table 8 presents the results of the truth table analysis. The table shows that two configurations are sufficient for policy design effectiveness. The first configuration-COHER*CONSIS*CONGR $\rightarrow$ EFFCT-confirms the theoretical model of Howlett and Cashore (Fig. 1) and supports the notion that the combination of coherent goals, consistent means, and congruence of goals and means explains policy design effectiveness. The second configuration- COHER $* \sim$ CONGR $\rightarrow$ EFFECT - states that incoherence in combination with incongruence is sufficient for policy design effectiveness. Furthermore, consistency is redundant in explaining policy design effectiveness for this pathway.

Table 6 Results of the necessity analysis

\begin{tabular}{lll}
\hline Condition tested & Consistency & Coverage \\
\hline COHER & 0.25 & 0.40 \\
$\sim$ COHER & 0.75 & 0.86 \\
CONSIS & 0.75 & 0.86 \\
$\sim$ CONSIS & 0.25 & 0.40 \\
CONGR & 0.25 & 1.00 \\
$\sim$ CONGR & 0.75 & 0.60 \\
\hline
\end{tabular}




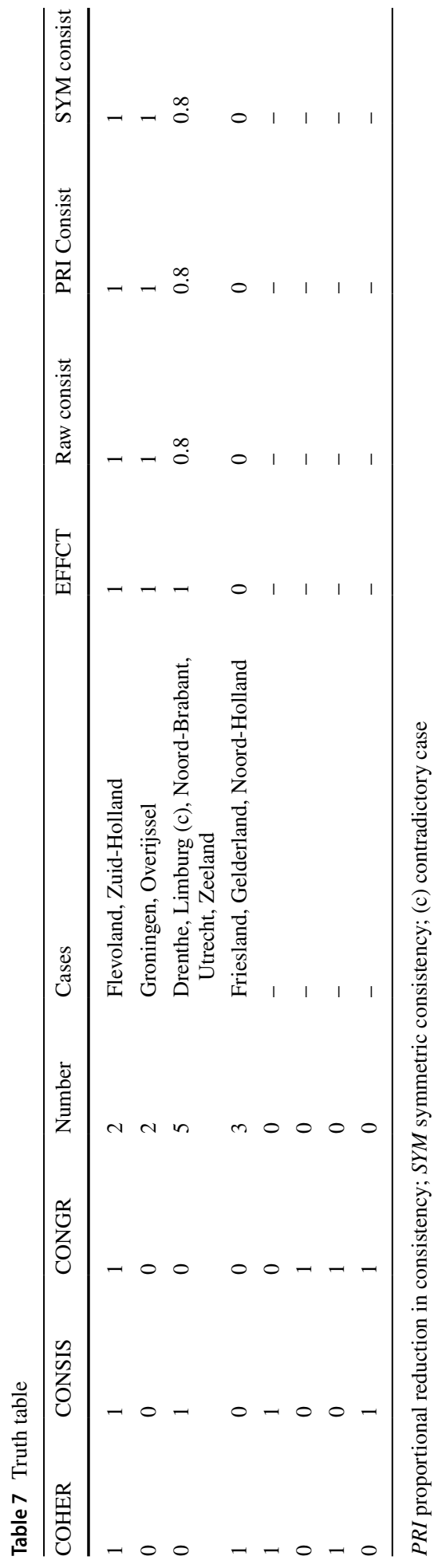


Table 8 Results table

\begin{tabular}{llll}
\hline $\begin{array}{l}\text { Frequency cutoff: } 2 \\
\text { Consistency cutoff: } 0.8\end{array}$ & Raw coverage & Unique coverage & Consistency \\
\hline COHER $^{*}$ CONSIS*CONGR & 0.25 & 0.25 & 1 \\
$\sim$ COHER $*$ CONGR & 0.75 & 0.75 & 0.857143
\end{tabular}

Solution coverage: 1

Solution consistency: 0.888889

Cases covered by COHER*CONSIS*CONGR: Flevoland, Zuid-Holland

Cases covered by $\sim$ COHER* ${ }^{*}$ CONGR: Drenthe, Groningen, Limburg (c), Noord-Brabant, Overijssel, Utrecht, Zeeland

(c) contradictory case

\section{Discussion}

\section{Interpreting and discussing QCA findings}

As part of the increased interest in policy design thinking, the development of effective configurations of goals and instruments has become a major theme within policy science and practice. A widely accepted assumption is that the fit of policy design componentsi.e., the combination of goal coherence, means consistence, and the congruence of goals and means-is to benefit effectiveness (Howlett \& Mukherjee, 2018; Howlett \& Rayner, 2013, 2018; Howlett, 2009, 2018b). Building on the theoretical advancements that have been made in conceptualizing the relationship between design fit and effectiveness, this study provides a first empirical assessment by applying Howlett's (2009) nested model on policy design in the context of policy integration. Our analysis did not find any necessary conditions for achieving policy design effectiveness. It did find two sufficient pathways for achieving policy design effectiveness. The first states that the fit of policy design components is sufficient for effectiveness, whereas the second states that policy design incoherence combined with incongruence is sufficient for effectiveness. This two-sided outcome suggests that the supportive relationship between policy design fit and policy design effectiveness is not as straightforward as theory suggests and provides some interesting footholds for further discussion. This section further elaborates and interprets the two pathways to policy design effectiveness and subsequently formulates implications of these findings for policy design and policy integration literature.

\section{Sufficiency of policy design fit for policy design effectiveness}

The first pathway states that the combination goal coherence, means consistency, and congruence of goals and means is sufficient for design effectiveness. In light of the object of this study, the outcomes suggest that when the goals and means of a policy design are of the same degree of integration across all three policy levels, this will be sufficient to promote desired policy integration. The pathway's consistency score of 1.0 indicates that all cases covered by this configuration support this result. The low coverage score $(0.25)$ indicates that this result is of limited empirical relevance as the specific configuration accounts for 2 out of 8 instances in which design effectiveness was observed. Interestingly, even though 
this outcome accords with a considerable theoretical body of literature on policy design (Howlett \& Mukherjee, 2018; Howlett \& Rayner, 2013, 2018; Howlett, 2009, 2018b), other than our analysis, very few empirical studies have been able to provide empirical verification. So far, only Reichardt and Rogge (2016) have demonstrated, based on interview data, that, in addition to credibility and stability of policy strategies, also policy design coherence, consistency, and congruence were considered by their respondents as important conditions for effectively promoting desired corporate innovation activities in offshore wind. Due to the considerable differences in the design of the current and Reichardt and Rogge's (2016) study, it is hard to draw comparisons and discuss outcomes in relation to one another. Overall, this pathway provides initial empirical proof in support of the theoretical assertion that a coherent, consistent, and congruent policy design effectively attains desired outcomes.

\section{Why incoherence and incongruence was sufficient for policy design effectiveness}

The second pathway states that the combination goal incoherence and incongruence of goals and means is sufficient for policy design effectiveness. This pathway, which followed out of the pairwise comparison of the configurations $\sim$ COHER $*$ CONSIS $* \sim$ CONGR $\rightarrow$ EFFECT and $\sim$ COHER $* \sim$ CONSIS $* \sim$ CONGR $\rightarrow$ EFFECT (see Table 7 ), indicates that discrepancies in the degree of integration between policy goals on the one hand, and between policy goals and policy means across policy levels, on the other hand, will be sufficient for promoting desired policy integration. Another aspect that stands out that consistency is redundant in explaining effectiveness for this pathway. From a policy design theory perspective, this outcome is highly unexpected for several reasons. First, because it suggests that the negation of policy design coherence and congruence is sufficient for policy design effectiveness. Furthermore, this outcome contradicts the findings of other empirical studies that found policy design coherence (Kern et al., 2017; Reichardt \& Rogge, 2016) as well as congruence (Kern \& Howlett, 2009; Reichardt \& Rogge, 2016; Rogge \& Schleich, 2018) to encourage goal attainment. Additionally, this pathway also contrasts several empirical studies that explicitly underline the importance of instrumental consistency in achieving desired outcomes (Kern \& Howlett, 2009; Kern et al., 2017; Reichardt \& Rogge, 2016; Rogge \& Schleich, 2018). The high coverage score (0.75) indicates the result to be of strong empirical relevance as it represents a considerable share of the cases. This underlines the relevance of finding and robust explanation for this counterintuitive outcome. To this end, an in-depth empirical and theoretical account is given for the two individual configurations that formed this pathway.

Concerning the configuration $\sim \mathrm{COHER} *$ CONSIS $*$ CONGR two aspects require clarification. First, what stands out already in Table 3 is that the observed incoherence and incongruence in all five cases was the result of the discrepancy between macro-level goals - qualified as integrated land use and transport - and all other policy design components - qualified as multimodal. It is relevant to note that these incoherencies and incongruences were exposed as a result of the multilevel framework that was adopted for this study; a single-level approach would not have found these mismatches. This raises a relevant question. Namely, to what extent do policy misfits between goals and means across policy levels impact effectiveness? A possible answer is provided by Howlett (2014a) who argues that the nested nature of the policy level cause design choices on each policy level to be constrained by higher-order components; high-level governance modes set the outside boundaries for the decision on the second level of policy or program operationalization, which in 
turn, shape the micro-level operationalization of a policy design. Consequently, this microlevel of policy design has to most significant influence on the outcomes that are achieved (Howlett, 2009). This suggests that if high-level ambitions are not correctly translated into the meso-level components, their influence on policy outcomes will be limited. Furthermore, the impact on effectiveness is expected to be minimal as policy design effectiveness is determined based on meso-level goals. This clarification provides a plausible explanation as to why in the current study the configuration $\sim$ COHER $*$ CONSIS $*$ CONGR was effective. However, for this explanation to hold, it is required to account for Limburg, where the same configuration led to a different, contradicting outcome.

Table 7 shows that Limburg is the only case where the configuration $\sim$ COHER $*$ CONSIS $*$ CONGR was ineffective. Following the strategies for resolving contradictions by Gerrits and Verweij (2018), an explanation was found by re-examining the original case-based material. A closer look at the Provincial Annual Reports of Limburg as well as Dirksen and Poppeliers's (2011) policy evaluation, revealed that policy action in Limburg was primarily geared toward attaining unimodal policy goals that were put down in the Provincial Coalition Agreement (Dutch: 'bestuursakkoord') instead of the multimodal goals that were defined in the strategic transport policy document, which was used to perform the QCA. This provides an explanation why the desired level of multimodal policy integration was not achieved in Limburg.

The configuration $\sim \mathrm{COHER}^{*} \sim \mathrm{CONSIS}^{*} \sim \mathrm{CONGR}$ was found effective in the cases Groningen and Overijssel. Looking more closely at the scoring of these individual cases in Table 3, it stands out that both cases managed to effectively promote desired integration across transport modes by using instruments that were designed for integrating land use and transport planning. From a policy design perspective, it is surprising that despite this incongruence effectiveness was achieved. Alternatively, from a policy integration point of view, it is sensible that instruments designed to promote integrated policy action within and across the domains of land use and transport can also be effective in promoting collective action within the domain transport.

\section{Implications and opportunities for future research}

This study adopted QCA methodology to explore the causal mechanisms behind policy design effectiveness through case-based research. QCA is especially appropriate for testing, refining and validating theory as it requires researchers to follow a well-structured and transparent analytic procedure that iterates between theory and case-based data (Befani, 2013). It should however be taken into account that due to its case-based and explanatory character, QCA findings cannot simply be decontextualized (Byrne, 2013). The results of the current analysis are therefore primarily representative for the Dutch regional transport planning context. Extrapolating case study findings beyond the target population is possible but should be done with care as it requires a degree of similarity between both cases (Greene \& David, 1984). Case-based research seeks to make analytic generalizations by assessing the applicability of theoretical conceptions in explaining observed outcomes within a specific context. In doing so, the current QCA provides powerful evidence on the generalizability of the notion that policy design fit benefits effectiveness. The contradicting outcomes of the QCA highlight that this relationship is more ambiguous; then literature puts forward. The process of interpreting and explaining the outcomes by returning to theory and case study data yielded several implications for policy design and policy integration literature. 


\section{Implications for policy design}

The main contribution of this study to policy design can be considered its empirical insights regarding the relationship between policy design fit and effectiveness. Even though the multilevel policy design model that was adopted in this study is receiving much attention in the more conceptual strand of policy design literature, it so far had not been empirically tested. This study found seemingly contrasting evidence on the relationship between policy design fit and effectiveness. On the one hand, our results provide empirical proof that supports the general theoretical consensus that matching goals and instruments across policy levels benefits design effectiveness (see e.g., Howlett \& Rayner, 2013, 2018; Howlett, 2014b). On the other hand, results show that neither coherence nor consistency nor congruence nor a combination of those features is necessary for policy design effectiveness. Furthermore, we found that under specific conditions, design effectiveness can be achieved despite the presence of incoherence, inconsistency, and incongruence. These outcomes clearly illustrate that the relationship between policy design fit and policy design effectiveness is not as straightforward as theory suggests.

Our multifaceted findings are in line with other empirical studies, which describe, based on different research approaches, various outcomes regarding the relationship between policy design fit and effectiveness. When it comes to promoting effectiveness Kern et al. (2017) describe the importance of coherence and consistency, Rogge and Schleich (2018) highlight the need for consistency and congruence, while Reichardt and Rogge (2016) indicate that coherence, consistency, and congruence are all needed. However, since these studies have adopted a single, meso-level approach to studying policy designs, and use different methodologies, their outcomes are difficult to compare to our findings. Essentially, a systematic assessment, based on the multilevel model like the one in this study had been missing in current design discussions. The outcomes of this study are therefore the first step toward a more profound understanding of the influence of the fit of policy design components across policy levels on effectiveness. It needs to be noted that the findings are, due to the specific operationalization of the model, closely related to the domain of policy integration. It would be essential to empirically study this model in other policy domains to get a better understanding of the apparently intricate interrelationship between policy design fit across policy levels and policy design effectiveness. The well-developed theoretical body of literature on policy design offers a robust analytical framework for designing well-structured and consistent empirical research across a broad field of applications, which would allow for triangulation of findings from a wide range of applications (George et al., 2005).

Another possible explanation for the multifaceted findings regarding the relationship between policy design fit and design effectiveness of this and other studies is that there may be other policy design attributes at play that might have influenced design effectiveness. The literature review presented an overview of the various attributes that have been introduced in recent studies. From these attributes, it is only certain that temporal influences as described by e.g., Howlett et al. (2018), Peters et al. (2018), and Rayner et al. (2017) can be ruled out as we tracked the development of the policy designs over time by analyzing annual reports and did not observe any changes in the typology for any of the design components. It is hard to reflect on the possible influence of the other attributes that have been linked to policy design effectiveness-i.e., policy design balance (e.g., Schmidt \& Sewerin, 2018), explicitness (e.g., Thomann, 2018), capacity 
(e.g., Mukherjee \& Bali, 2019), and goodness-of-fit (e.g., Peters et al., 2018)—on our findings as existing studies on those attributes lack empirical testing as discussions have remained predominantly explorative and conceptual of nature. This once more underlines the need for empirical research that studies the impact of policy design attributes on effectiveness, by adopting policy design effectiveness as the dependent variable. This would require conformance and performance approaches to policy design evaluation to further develop into complementary approaches for assessing policy design effectiveness (see e.g., Faludi, 1989; Mastop \& Faludi, 1997).

In addition to existing studies on the relationship between policy design fit and effectiveness, the outcomes of this study provide a novel perspective on the concept of policy design fit. Currently, the features that determine policy design fits are presented as a duality; a policy design is either coherent, consistent, and/or congruent or it is not. This goes against our empirical findings, which suggest that when taking different policy levels into account, varying degrees of incoherence, inconsistency, and incongruence affect effectiveness differently. Importantly, these need not result in ineffectiveness. Especially when these are found at a macro-level they have limited impact on effectiveness. As such, this argues for a much more nuanced conceptualization of policy design coherence, consistency, and congruence. This would be an interesting avenue for further research to explore.

\section{Implications for policy integration}

Building on Candel and Biesbroek (2016), this study analyzed how effectiveness discrepancies in the level of integration of interrelated policy design components. As shown in Table 2, the current study differentiates between three levels of integration: sub-sectoral fragmentation (unimodal planning), intra-sectoral integration (multimodal planning), and intersectoral integration (integrated land use and transport planning). The individual scoring of our cases in Table 3 shows that, in line with Candel and Biesbroek (2016), discrepancies in the level of integration within a single policy design are 'the rule rather than exception.' Interestingly, it was found that these a-synchronicities under specific circumstances do not necessarily stand in the way of achieving effectiveness. More specifically, results indicate that instrument mixes, which are of a higher degree of integration than the related policy goals can be effective in promoting desired integration. This was observed in both Groningen and Overijssel. In these cases, intersectoral instrument mixes were used to effectively promote desired processes of intra-sectoral policy integration. It could, however, be argued that such a-synchronicity is inefficient since instruments promote higher levels of collaboration and interaction throughout the public sector than is necessary to achieve desired outcomes. Additionally, the effective policy design of Groningen illustrates that intra-sectoral objectives may be incoherently operationalized to sub-sectoral on-theground measures as long as there are instruments in place that help to coordinate sub-sectoral policy action in line with intra-sectoral objectives. This outcome resonates well with work by Cejudo and Michel (2017) who argue that policy integration may be achieved through overarching procedural instruments that guide sub-sectoral policy action in line with a shared overarching integrative logic.

The results of the analysis suggest that the formulation and adoption of a shared overarching logic to guide integrated government action is not straightforward. It stands out from the observed discrepancies in Table 3 that, even though it is widely recognized that policy-making should take into consideration intersectoral relationship between land use and transport, only a few organizations have successfully translated these integrative 
ambitions to lower policy levels. This observation is in line with work by Rayner and Howlett (2009), who noted that integrated goals are rarely adopted unless there is a widespread dissatisfaction of existing approach, as a variety of institutional barriers-financial, organizational, cultural, legislative, political, and technical — that have to be overcome (cf. Hull, 2010).

The outcomes of this study add to an emerging body of research on the appropriate policy instruments for giving effect to these integrated goals (e.g., Marsden \& Reardon, 2017; Mu \& de Jong, 2016; van Geet et al., 2021). Although findings have been derived from the context of transport planning, the analytic generalizations that can be drawn from this study (see Polit \& Beck, 2010) carry interesting implications for debates on policy integration in other sectors such as health policy, climate policy, environmental policy, and energy policy. A key insight that was obtained from the current study is that the design of the instrument mix plays a crucial role in supporting and steering the integrated government action that is required to achieve policy goals that are shared between multiple sectors. In line with Candel and Biesbroek (2016) and Cejudo and Michel (2017), our analysis underlines the importance of overarching policy instruments that allow to steer and coordinate sectoral or sub-sectoral action in line with shared goals. Our outcomes indicate that in line with the degree of integration of the adopted policy goals-i.e., the range of sectors or sub-sectors that are involved-instrument mixes need be at least of the same degree of integration.

\section{Conclusion}

This study applied the multilevel approach to policy design to determine which conditions of policy design fit-coherence, consistency, and congruence-are necessary or sufficient for policy design effectiveness in the context of policy integration. The QCA that was performed revealed no necessary conditions or combinations of conditions and showed two configurations of conditions to be sufficient for policy design effectiveness. The first configuration confirms that the presence of policy design coherence, consistency, and congruence is sufficient for policy design effectiveness. The second configuration is counterintuitive and states that the combination incoherence and incongruence is sufficient for policy design effectiveness.

An in-depth theoretical and empirical interpretation of the QCA outcomes leads to the conclusion that when it comes to promoting policy integration, achieving policy design effectiveness is not a matter of simply matching goals and means across policy levels. In specific situations, a policy design is still effective despite being incoherent, inconsistent, or incongruent. For example, mismatches between macro- and meso-level policy design components will not necessarily impede design effectiveness when meso- and micro-level components are aligned. That is, there are different degrees of policy design coherence, consistency, and congruence that impact effectiveness differently. Furthermore, when policy means are inconsistent but show a higher degree of integration, these means can still be effective even though this makes them less efficient in achieving the desired outcomes. Hereby, our study shows that the relationship between policy design fit and policy design effectiveness is more intricate in practice than theory suggests. More empirical research is needed to complement the initial steps made in this study to get a better understanding of the relationship between policy design fit and effectiveness from a multilevel policy design perspective. 


\section{Appendix: Reference list of data sources}

Buck Consultants International, 2016. Monitor Logistiek \& Goederenvervoer voor Nederland 2016. Nijmegen.

CBS, 2017. Mobiliteitsmonitor Regio Groningen-Assen 2017. Den Haag: CBS Den Haag.

Dirksen, R. and Poppeliers, R., 2011. Evaluatie OV-Beleid provincie Limburg. Zoetermeer: De Onderzoeksbank Limburg.

Drenthe, 2007a. Provinciaal Verkeers- en Vervoersplan Drenthe: Kaders en Ambities 2007-2020. Assen: Provincie Drenthe.

Drenthe, 2007b. Provinciaal Verkeers- en Vervoersplan Drenthe: Uitvoeringsagenda 2007-2012. Assen: Provincie Drenthe.

Drenthe, 2009a. Provinciaal Uitvoeringsprogramma verkeer en vervoer 2009. Assen: Provincie Drenthe.

Drenthe, 2009b. Jaarstukken 2008. Assen: Provincie Drenthe.

Drenthe, 2010a. Investeringsprogramma verkeer en vervoer 2011-2020. Assen: Provincie Drenthe.

Drenthe, 2010b. Jaarstukken 2009. Assen: Provincie Drenthe.

Drenthe, 2011. Jaarstukken 2010. Assen: Provincie Drenthe.

Drenthe, 2012. Jaarstukken 2011. Assen: Provincie Drenthe.

Drenthe, 2014. Jaarstukken 2013. Assen: Provincie Drenthe.

Drenthe, 2015. Jaarstukken 2014. Assen: Provincie Drenthe.

Drenthe, 2017. Jaarstukken 2016. Assen: Provincie Drenthe.

Drenthe, 2018. Jaarstukken 2017. Assen: Provincie Drenthe.

Drenthe, 2019. Cijfers Verkeer en Vervoer [online]. Available from: https://www.provi ncie.drenthe.nl/feitenencijfers/cijfers/verkeer-vervoer/ [Accessed 25 Nov 2019].

Flevoland, 1994. Toelichting op Verordening: Provinciale Commissie Vervoerberaad Flevoland. Lelystad: Provinciale Staten van Flevoland.

Flevoland, 2006a. Nota Mobiliteit Flevoland. Lelystad: Provincie Flevoland.

Flevoland, 2006b. Omgevingsplan Flevoland 2006. Lelystad: Provincie Flevoland.

Flevoland, 2007. Provinciaal Meerjarenprogramma Infrastructuur, Ruimte en Transport 2007-2011. Lelystad: Provincie Flevoland.

Flevoland, 2008a. Beleidsregel locatiebeleid Stedelijk Gebied. Lelystad: Gedeputeerde Staten van Flevoland.

Flevoland, 2008b. Jaarverslag \& Jaarrekening 2007. Lelystad: Provincie Flevoland. Flevoland, 2009. Jaarverslag \& Jaarrekening 2008. Lelystad: Provincie Flevoland. Flevoland, 2010. Jaarverslag \& Jaarrekening 2009. Lelystad: Provincie Flevoland. Flevoland, 2011. Jaarverslag \& Jaarrekening 2010. Lelystad: Provincie Flevoland. Flevoland, 2012. Jaarverslag \& Jaarrekening 2011. Lelystad: Provincie Flevoland. Flevoland, 2013. Jaarstukken 2012. Lelystad: Provincie Flevoland. Flevoland, 2014. Jaarstukken 2013. Lelystad: Provincie Flevoland. Flevoland, 2015. Jaarstukken 2014. Lelystad: Provincie Flevoland. Flevoland, 2016. Jaarstukken 2015. Lelystad: Provincie Flevoland. Flevoland, 2017. Jaarstukken 2016. Lelystad: Provincie Flevoland.

Friesland, 2006a. Provinciaal verkeer- en vervoerplan: pvvp 2006. Leeuwarden: Provincie Friesland.

Friesland, 2006b. Streekplan Fryslân 2007 Om de kwaliteit fan de romte. Leeuwarden: Provinciale Staten van Fryslân. 
Friesland, 2008. Jaarverslag 2007. Leeuwarden: Gedeputeerde Staten van Fryslân. Friesland, 2009. Jaarstukken 2008. Leeuwarden: Gedeputeerde Staten van Fryslân. Friesland, 2010a. Jaarstukken 2009. Leeuwarden: Gedeputeerde Staten van Fryslân. Friesland, 2010b. Evaluatie PVVP 2006: Deel 1 Beoordeling van het PVVP. Leeuwarden: Provincie Friesland.

Friesland, 2010c. Evaluatie PVVP 2006: Deel 2 Monitoring, trends en ontwikkelingen. Leeuwarden: Provincie Friesland.

Friesland, 2011. Jaarstukken 2010. Leeuwarden: Gedeputeerde Staten van Fryslân. Friesland, 2012. Jaarstukken 2011. Leeuwarden: Gedeputeerde Staten van Fryslân. Friesland, 2013. Jaarstukken 2012. Leeuwarden: Gedeputeerde Staten van Fryslân. Friesland, 2014a. Útfieringsprogramma Ferkear en Ferfier 2015. Leeuwarden: Provincie Friesland.

Friesland, 2014b. Jaarstukken 2013. 2014: Gedeputeerde Staten van Fryslân.

Friesland, 2015. Jaarstukken 2014. Leeuwarden: Gedeputeerde Staten van Fryslân. Friesland, 2016. Jaarstukken 2015. Leeuwarden: Gedeputeerde Staten van Fryslân.

Friesland, 2020. Fryslân in Cijfers [online]. Available from: https://friesland.databank. nl/jive/jivereportcontents.ashx?report=s5home_abf [Accessed 17 Apr 2020].

GA, 2006. Netwerkanalyse Regio Groningen-Assen 2030. Groningen: Regio GroningenAssen stedelijk netwerkt.

GA, 2013. Bereikbaarheid regio Groningen-Assen: Geactualiseerde Netwerkanalyse 2013. Groningen: Regio Groningen-Assen stedelijk netwerkt.

Geerdinck, M., Kamphorst, M., Stinissen, A., and de Vries, I., 2017. Mobiliteitsmonitor Regio Groningen-Assen 2017. Den Haag: CBS Den Haag.

Gelderland, 2004. Provinciaal Verkeer en Vervoerplan 2: Op weg naar duurzame mobiliteit, deel c Bijlagenrapport. Arnhem: Provincie Gelderland.

Gelderland, 2005. Streekplan Gelderalnd 2005. Arnhem: Provincie Gelderland.

Gelderland, 2006a. Herijking Netwerknota Verbinden en Ontsluiten. Arnhem: Provincie Gelderland.

Gelderland, 2006b. Netwerkanalyse Gelderland: Een verkenning voor de periode 20102020. Arnhem: Gedeputeerde Staten van Gelderland.

Gelderland, 2007a. Dynamische beleidsagenda 2007-2008. Arnhem: Provincie Gelderland.

Gelderland, 2007b. Regionaal actieprogramma Verkeer en Vervoer 2007: NoordVeluwe. Arnhem: Provincie Gelderland.

Gelderland, 2007c. Regionaal actieprogramma Verkeer en Vervoer 2007: Achterhoek. Arnhem: Provincie Gelderland.

Gelderland, 2013a. Meerjaren Investerings Agenda Mobiliteit. Arnhem: Provincie Gelderland.

Gelderland, 2013b. Beleidsrekening 2012. Arnhem: Provincie Gelderland.

Gelderland, 2014. Beleidsrekening 2013. Arnhem: Provincie Gelderland.

Gelderland, 2015. Beleidsrekening 2014. Arnhem: Provincie Gelderland.

Gelderland, 2020. Kaarten en cijfers [online]. Available from: https://www.gelderland. nl/Kaartenencijfers [Accessed 20 Apr 2020].

Govers, B. and Roelofsen, D., 2017. Regionale verdieping NMCA: HOV-net Groningen. Deventer: Goudappel Coffeng.

Groningen, 2009a. Provinciaal meerjarenprogramma transport. Groningen: Provincie Groningen.

Groningen, 2009b. Provinciaal omgevingsplan 2009-2013. Groningen: Provincie Groningen. 
Groningen, 2009c. Omgevingsverordening provincie Groningen 2009. Groningen: Provinciale Staten van Groningen.

Groningen, 2010. POP-Uitvoeringsprogramma 2010. Groningen: Gedeputeerde Staten van Groningen.

Groningen, 2012. Productenrekening 2011. Groningen: Provincie Groningen.

Groningen, 2013. Productenrekening 2012. Groningen: Provincie Groningen.

Groningen, 2014. Productenrekening 2013. Groningen: Provincie Groningen.

Groningen, 2015. Rekening 2014: Geïntegreerde Programma- en Productenrekening 2014. Groningen: Provincie Groningen.

Groningen, 2016. Rekening 2015: Geïntegreerde programma- en productenrekening 2015. Groningen: Provincie Groningen.

Groningen, 2017. Rekening 2016. Groningen: Provincie Groningen.

Groningen, 2018. Rekening 2017. Groningen: Provincie Groningen.

Groningen, 2019. Rekening 2018. Groningen: Provincie Groningen.

Groningen, 2020a. De staat van Groningen [online]. Available from: https://destaatvan groningen.nl/ [Accessed 20 Apr 2020].

Groningen, 2020b. Monitor Groningen [online]. Available from: http://www.monitorgro ningen.nl/ [Accessed 20 Apr 2020].

Limburg, 2006. Provinciaal Omgevingsplan Limburg. Maastricht: Provincie Limburg.

Limburg, 2007a. Provinciaal Verkeers- en Vervoersplan Limburg. Maastricht: Provincie Limburg.

Limburg, 2007b. Goederenvervoerplan Provincie Limburg: Meer dan bereikbaarheid alleen. Maastricht: Provincie Limburg.

Limburg, 2009. Uitvoeringsprogramma Provinciaal Verkeers- en Vervoersplan. Maastricht: Provincie Limburg.

Limburg, 2010. Jaarverslag 2009: Deel I Programmaverantwoording. Maastricht: Provincie Limburg.

Limburg, 2011. Jaarverslag 2010: Deel I Programmaverantwoording. Maastricht: Provincie Limburg.

Limburg, 2012. Jaarverslag 2011: Deel I Programmaverantwoording. Maastricht: Provincie Limburg.

Limburg, 2013. Jaarstukken 2012. Maastricht: Provincie Limburg.

Limburg, 2014. Jaarstukken 2013. Maastricht: Provincie Limburg.

Limburg, 2015. Jaarstukken 2014. Maastricht: Provincie Limburg.

Limburg, 2016. Jaarstukken 2015. Maastricht: Provincie Limburg.

Limburg, 2017. Jaarstukken 2016. Maastricht: Provincie Limburg.

Limburg, 2018. Jaarstukken 2017. Maastricht: Provincie Limburg.

Limburg, 2020. Staat van Limburg: Leef- en vestigingsklimaat [online]. Available from: https://dashboardlimburg.nl/staatvanlimburg/ [Accessed 20 Apr 2020].

Metropool Regio Eindhoven, 2020. Metropoolregio Eindhoven [online]. Available from: https://metropoolregioeindhoven.nl/ [Accessed 20 Apr 2020].

MuConsult, 2017. Monitor gedecentraliseerde treindiensten Limburg. Amersfoort: MuConsult B.V.

Noord-Brabant, 2006a. Kiezen en Uitvoeren: Dynamische beleidsagenda 2006-2010.'s-Hertogenbosch: Provincie Noord-Brabant.

Noord-Brabant, 2006b. Provinciaal Verkeers- en Vervoersplan Noord-Brabant: deel 1 Kaders en Ambities 2006-2020.'s-Hertogenbosch: Provincie Noord-Brabant.

Noord-Brabant, 2006c. Provinciaal Verkeers- en Vervoersplan Noord-Brabant: deel 2 Bouwstenen.'s-Hertogenbosch: Provincie Noord-Brabant. 
Noord-Brabant, 2006d. Netwerkanalyse BrabantStad.'s-Hertogenbosch: Provincie Noord-Brabant.

Noord-Brabant, 2006e. Provinciaal Verkeers- en Vervoersplan Noord-Brabant: deel 3 Bijlagen.'s-Hertogenbosch: Provincie Noord-Brabant.

Noord-Brabant, 2007. Stand van zaken uitvoeringsstrategie PVVP.'s-Hertogenbosch: Gedeputeerde Staten van Noord-Brabant.

Noord-Brabant, 2008. Notitie regionale uitvoeringsprogramma's 2008 Cofinancieringsregeling Verkeer en Vervoer.'s-Hertogenbosch: Gedeputeerde Staten van NoordBrabant.

Noord-Brabant, 2010. Jaarstukken 2009.'s-Hertogenbosch: Provincie Noord-Brabant.

Noord-Brabant, 2011a. Sturen op uitvoering: Dynamische beleidsagenda 2012-2016.'s-Hertogenbosch: Provincie Noord-Brabant.

Noord-Brabant, 2011b. Evaluatie gebiedsgerichte samenwerking GGA.'s-Hertogenbosch: Gedeputeerde Staten van Noord-Brabant.

Noord-Brabant, 2011c. Jaarstukken 2010.'s-Hertogenbosch: Provincie Noord-Brabant. Noord-Brabant, 2012. Jaarstukken 2011.'s-Hertogenbosch: Provincie Noord-Brabant. Noord-Brabant, 2013. Jaarstukken 2012.'s-Hertogenbosch: Provincie Noord-Brabant. Noord-Brabant, 2014a. Brabants Meerjarenprogramma Infrastructuur en Transport 2014-2018.'s-Hertogenbosch: Provincie Noord-Brabant.

Noord-Brabant, 2014b. Jaarstukken 2013.'s-Hertogenbosch: Provincie Noord-Brabant. Noord-Brabant, 2015. Jaarstukken 2014.'s-Hertogenbosch: Provincie Noord-Brabant. Noord-Brabant, 2016. Jaarstukken 2015.'s-Hertogenbosch: Provincie Noord-Brabant. Noord-Brabant, 2017. Jaarstukken 2016.'s-Hertogenbosch: Provincie Noord-Brabant. Noord-Brabant, 2019. Bussen in Brabant: Trends in het regionaal OV 2012-2018.'s-Hertogenbosch: Provincie Noord-Brabant.

Noord-Brabant, 2020. Brabant databank [online]. Available from: https://brabant.datab ank.nl/ [Accessed 20 Apr 2020].

Noord-Holland, 2008. Provinciaal Verkeers- en Vervoerplan: Actualisatie van het PVVP 2007-2013. Haarlem: Provincie Noord-Holland.

Noord-Holland, 2010a. Structuurvisie Noord-Holland 2040: Kwailiteit door veelzijdigheid. Haarlem: Provinciale Staten van Noord-Holland.

Noord-Holland, 2010b. Jaarverslag 2009. Haarlem: Provincie Noord-Holland.

Noord-Holland, 2011. Jaarstukken 2010. Haarlem: Provincie Noord-Holland.

Noord-Holland, 2012a. Provinciaal Meerjarenprogramma Infrastructuur 2012-2016. Haarlem: Provincie Noord-Holland.

Noord-Holland, 2012b. Jaarstukken 2011. Haarlem: Provincie Noord-Holland.

Noord-Holland, 2013. Jaarstukken 2012. Haarlem: Provincie Noord-Holland.

Noord-Holland, 2014a. Besluit tot vaststelling van de Provinciale Ruimtelijke Verordening. Haarlem: Provinciale Staten van Noord-Holland.

Noord-Holland, 2014b. Jaarstukken 2013. Haarlem: Provincie Noord-Holland.

Noord-Holland, 2015. Jaarstukken 2014. Haarlem: Provincie Noord-Holland.

Noord-Holland, 2016a. Monitor OV-knooppunten. Haarlem: Provincie Noord-Holland.

Noord-Holland, 2016b. Jaarrekening 2015. Haarlem: Provincie Noord-Holland.

Noord-Holland, 2017. Jaarrekening 2016. Haarlem: Provincie Noord-Holland.

Noord-Holland, 2018. Jaarrekening 2017. Haarlem: Provincie Noord-Holland.

O\&S Heerlen, 2011. Monitor Effecten mobiliteitsmanagement. Heerlen: Bureau Onderzoek en Statistiek Heerlen.

OV Bureau, 2017. Trend monitor 2016. Assen: ov bureau groningen drenthe. 
Overijssel, 2009a. Omgevingsvisie Overijssel: visie en uitvoeringsprogramma voor de ontwikkeling van de fysieke leefomgeving. Zwolle: Provincie Overijssel.

Overijssel, 2009b. Omgevingsverordening Overijssel 2009. Zwolle: Provinciale Staten van Overijssel.

Overijssel, 2009c. Dynamische Beleidsagenda Mobiliteit 2010. Zwolle: Provincie Overijssel.

Overijssel, 2011. Jaarverslag 2010: Vertrouwen, verbinden, versnellen. Zwolle: Provincie Overijssel.

Overijssel, 2013. Jaarverslag 2012: Inspireren, innoveren, investeren. Zwolle: Provincie Overijssel.

Overijssel, 2014. Midterm Review Omgevingsvisie: werking uitvoeringsmodel en ontwikkeling ambities. Zwolle: Provincie Overijssel.

Overijssel, 2017. Catalogus Gebiedskenmerken. Zwolle: Provincie Overijssel.

Overijssel, 2020a. de Staat van Overijssel [online]. Available from: https://destaatvan. overijssel.nl/ [Accessed 20 Apr 2020].

Overijssel, 2020b. provincie Overijssel Monitor [online]. Available from: http://monit oroverijssel.nl/ [Accessed 20 Apr 2020].

Panteia, 2015. Goederenvervoer van en naar Frysian Ports. Zoetermeer.

Panteia, 2019. Kwantificering CO2 effecten Duurzame personenmobiliteit Flevoland. Zoetermeer.

Rekenkamer Oost-Nederland, 2011. Bestemming bereikt: Onderzoek naar de maatschappelijke effecten van grote provinciale wegenprojecten in Gelderland. Deventer.

ROA, 2006. Regionaal Infrastructuur Programma 2006. Amsterdam: Regionaal Orgaan Amsterdam.

RWB, 2014. Uitvoeringsprogramma mobiliteit West-Brabant 2015-2020. Breda: Regio West-Brabant.

Schuldenberg, R., Leidelmeijer, K., van der Reijden, H., Wouters, R., Drentje, A., and Giesbergs, I., 2013. Gelderse stedenmonitor 2013: Algemene rapportage. Amsterdam: RIGO Research en Advies BV.

Tableau Public, 2020. Beleidsinformatie Flevoland [online]. Available from: https:// public.tableau.com/profile/beleidsinformatie.flevoland\#!/ [Accessed 16 Apr 2020].

Utrecht, 2003a. Meerjaren actieprogramma verkeer en vervoer 2004-2015. Utrecht: Provincie Utrecht.

Utrecht, 2003b. Eindrapportage strategische gebiedsperspectieven (sgp'en). Utrecht: Gedeputeerde Staten van Utrecht.

Utrecht, 2004. Streekplan 2005-2015. Utrecht: Provincie Utrecht.

Utrecht, 2007. Gezamenlijk Beoordelingskader: Pakketstudies Utrecht. Utrecht: Provincie Utrecht.

Utrecht, 2008a. Uitvoeringsprogramma Mobiliteitsplan 2008-2012. Utrecht: Provincie Utrecht.

Utrecht, 2008b. Jaarrekening 2007. Utrecht: Provincie Utrecht.

Utrecht, 2009. Jaarrekening 2008. Utrecht: Provincie Utrecht.

Utrecht, 2010a. Strategisch Mobiliteitsplan provincie Utrecht 2004-2020. Utrecht: Provincie Utrecht.

Utrecht, 2010b. Bijlagendocument Tussenbalans 2010: Strategisch Mobiliteitsplan Provincie Utrecht 2004-2020 (SMPU+). Utrecht: Provincie Utrecht.

Utrecht, 2010c. Tussenbalans 2010: Strategisch Mobiliteitsplan Provincie Utrecht 2004-2020 (SMPU+). Utrecht: Provincie Utrecht. 
Utrecht, 2010d. Jaarrekening 2009. Utrecht: Provincie Utrecht.

Utrecht, 2011. Jaarrekening 2010. Utrecht: Provincie Utrecht.

Utrecht, 2012. Jaarrekening 2011. Utrecht: Provincie Utrecht.

Utrecht, 2013. Jaarrekening 2012. Utrecht: Provincie Utrecht.

Utrecht, 2014. Jaarrekening 2013. Utrecht: Provincie Utrecht.

Utrecht, 2015. Jaarrekening 2014. Utrecht: Provincie Utrecht.

Utrecht, 2016. Jaarrekening 2015. Utrecht: Provincie Utrecht.

Utrecht, 2020. De Staat van Utrecht [online]. Available from: https://staatvanutrecht.nl/ [Accessed 20 Apr 2020].

V\&W, 2006. Netwerkanalyse Noordvleugel. Den Haag: Ministerie van Verkeer en Waterstaat \& Plaform Bereikbaarheid Noordvleugel.

Witmond, B. and Lahaye, S., 2006. Eindrapport MIT-Verkenning en Netwerkanalyse Regio Utrecht. Utrecht: Publicatiebank IenW.

Zeeland, 2004. Meerjarenprogramma Infrastructuur Zeeland 2005-2009. Middelburg: Provincie Zeeland.

Zeeland, 2006a. Bereikbaarheid op maat: Netwerkanalyse Zeeland. Middelburg: Provincie Zeeland.

Zeeland, 2006b. Omgevingsplan Zeeland 2006-2012. Middelburg: Provincie Zeeland. Zeeland, 2008. Actieprogramma PVVP Zeeland 2008. Middelburg: Provincie Zeeland. Zeeland, 2010a. Actieprogramma PVVP Zeeland 2010. Middelburg: Provincie Zeeland. Zeeland, 2010b. Jaarstukken 2009: Voor en door Zeeuwen. Middelburg: Provincie Zeeland.

Zeeland, 2011. Jaarstukken 2010: Voor en door Zeeuwen. Middelburg: Provincie Zeeland.

Zeeland, 2012a. Voortgangsrapportage PVVP. Middelburg: Provincie Zeeland.

Zeeland, 2012b. Jaarstukken 2011: Voor en door Zeeuwen. Middelburg: Provincie Zeeland.

Zeeland, 2013a. Actieprogramma PVVP 2013. Middelburg: Provincie Zeeland.

Zeeland, 2013b. Jaarverslag 2012. Middelburg: Provincie Zeeland.

Zeeland, 2014. Jaarverslag 2013. Middelburg: Provincie Zeeland.

Zeeland, 2015. Jaarverslag 2014. Middelburg: Provincie Zeeland.

Zeeland, 2016. Jaarstukken 2015. Middelburg: Provincie Zeeland.

Zeeland, 2017. Jaarstukken 2016. Middelburg: Provincie Zeeland.

Zeeland, 2018. Jaarstukken 2017. Middelburg: Provincie Zeeland.

Zeeland, 2019. Jaarstukken 2018. Middelburg: Provincie Zeeland.

Zuid-Holland, 2004a. Beheerst groeien: Provinciaal Verkeer- en vervoerplan 20022020. Den Haag: Provincie Zuid-Holland.

Zuid-Holland, 2004b. Provinciale Ruimtelijke Structuurvisie Zuid-Holland 2020. Den Haag: Provincie Zuid-Holland.

Zuid-Holland, 2005. Provinciaal Verkeer- en Vervoerplan 2002-2020: Deel B de beleidsagenda. Den Haag: Provincie Zuid-Holland.

Zuid-Holland, 2006. Streekplan Zuid-Holland Oost: Zuidplas. Den Haag: Provincie Zuid-Holland.

Zuid-Holland, 2011. PVVP-monitor 2010. Den Haag: Provincie Zuid-Holland. Zuid-Holland, 2012a. PVVP-monitor 2011. Den Haag: Provincie Zuid-Holland. Zuid-Holland, 2012b. Jaarstukken 2011. Middelburg: Provincie Zuid-Holland. Zuid-Holland, 2013. Jaarstukken 2012. Middelburg: Provincie Zuid-Holland. Zuid-Holland, 2014. Jaarstukken 2013. Middelburg: Provincie Zuid-Holland. Zuid-Holland, 2015. Jaarrekening 2014. Den Haag: Provincie Zuid-Holland. 
Zuid-Holland, 2018. Evaluatie Programma mobiliteit 2014-2018. Den Haag: Provincie Zuid-Holland.

Zuid-Holland, 2020. Staat van Zuid-Holland [online]. Available from: https://staatvan. zuid-holland.nl/ [Accessed 20 Apr 2020].

Supplementary Information The online version contains supplementary material available at https://doi. org/10.1007/s11077-021-09429-z.

Funding This research was financially supported by the cooperation between the Faculty of Spatial Sciences of the University of Groningen and Rijkswaterstaat.

Open Access This article is licensed under a Creative Commons Attribution 4.0 International License, which permits use, sharing, adaptation, distribution and reproduction in any medium or format, as long as you give appropriate credit to the original author(s) and the source, provide a link to the Creative Commons licence, and indicate if changes were made. The images or other third party material in this article are included in the article's Creative Commons licence, unless indicated otherwise in a credit line to the material. If material is not included in the article's Creative Commons licence and your intended use is not permitted by statutory regulation or exceeds the permitted use, you will need to obtain permission directly from the copyright holder. To view a copy of this licence, visit http://creativecommons.org/licenses/by/4.0/.

\section{References}

Arts, J., Filarski, R., Jeekel, H., \& Toussaint, B. (2016). Builders and planners: A history of land-use and infrastructure planning in the Netherlands. Eburon Academic Publishers.

Arts, J., Hanekamp, T., \& Dijkstra, A. (2014). Integrating land-use and transport infrastructure planning: Towards adaptive and sustainable transport infrastructure. Transport Research Arena.

Bali, A. S., Capano, G., \& Ramesh, M. (2019). Anticipating and designing for policy effectiveness. Policy and Society, 38(1), 1-13.

Bali, A. S., \& Ramesh, M. (2018). Policy capacity: A design perspective. Routledge handbook of policy design (pp. 331-343). Routledge.

Banister, D. (2008). The sustainable mobility paradigm. Transport Policy, 15(2), 73-80.

Basurto, X., \& Speer, J. (2012). Structuring the calibration of qualitative data as sets for qualitative comparative analysis (QCA). Field Methods, 24(2), 155-174.

Befani, B. (2013). Between complexity and generalization: Addressing evaluation challenges with QCA. Evaluation, 19(3), 269-283.

Bertolini, L., Le Clercq, F., \& Kapoen, L. (2005). Sustainable accessibility: A conceptual framework to integrate transport and land use plan-making. Two test-applications in the Netherlands and a reflection on the way forward. Transport Policy, 12(3), 207-220.

Busscher, T., Tillema, T., \& Arts, J. (2015). In search of sustainable road infrastructure planning: How can we build on historical policy shifts? Transport Policy, 42, 42-51.

Byrne, D. (2013). Evaluating complex social interventions in a complex world. Evaluation, 19(3), 217-228.

Candel, J. J. L., \& Biesbroek, R. (2016). Toward a processual understanding of policy integration. Policy Sciences, 49(3), 211-231.

Capano, G., \& Howlett, M. (2019). Causal logics and mechanisms in policy design: How and why adopting a mechanistic perspective can improve policy design. Public Policy and Administration, 36(2), $141-162$.

Cashore, B., \& Howlett, M. (2007). Punctuating which equilibrium? Understanding thermostatic policy dynamics in pacific northwest forestry. American Journal of Political Science, 51(3), 532-551.

Cejudo, G. M., \& Michel, C. L. (2017). Addressing fragmented government action: Coordination, coherence, and integration. Policy Sciences, 50(4), 745-767.

Curtis, C., \& James, B. (2004). An institutional model for land use and transport integration. Urban Policy and Research, 22(3), 277-297. 
Dirksen, R., \& Poppeliers, R. (2011). Evaluatie OV-Beleid Provincie Limburg. OVnetwerk/NEA, Zoetermeer.

Doremus, H. (2003). A policy portfolio approach to biodiversity protection on private lands. Environmental Science and Policy, 6(3), 217-232.

de Block, D., \& Vis, B. (2018). Addressing the challenges related to transforming qualitative into quantitative data in qualitative comparative analysis. Journal of Mixed Methods Research, 13(4), 503-535.

Faludi, A. (1989). Conformance vs. performance: Implications for evaluation. Impact Assessment, 7(2-3), $135-151$.

George, A. L., Bennett, A., Lynn-Jones, S. M., \& Miller, S. E. (2005). Case Studies and Theory Development in the Social Sciences. MIT Press.

Gerrits, L., \& Verweij, S. (2018). The evaluation of complex infrastructure projects: a guide to qualitative comparative analysis. Edward Elgar Publishing. https://doi.org/10.4337/9781783478422

Greene, D., \& David, J. L. (1984). A research design for generalizing from multiple case studies. Evaluation and Program Planning, 7(1), 73-85.

Hall, P. A. (1993). Policy paradigms, social learning, and the state: The case of economic policymaking in Britain. Comparative Politics, 25(3), 275-296.

Heeres, N. (2017). Toward area-oriented approaches in infrastructure planning: Development of national highway networks in a local spatial context. University of Groningen.

Heeres, N., Tillema, T., \& Arts, J. (2012). Integration in Dutch planning of motorways: From 'line' towards 'area-oriented' approaches. Transport Policy, 24, 148-158.

Heeres, N., Tillema, T., \& Arts, J. (2016). Dealing with interrelatedness and fragmentation in road infrastructure planning: An analysis of integrated approaches throughout the planning process in the Netherlands. Planning Theory and Practice, 17(3), 421-443.

Howlett, M. (2009). Governance modes, policy regimes and operational plans: A multi-level nested model of policy instrument choice and policy design. Policy Sciences, 42(1), 73-89.

Howlett, M. (2014a). Policy Design: What, Who, How and Why? In C. Halpern, P. Lascoumes, \& P. Le Galès (Eds.), L'instrumentation de l'action publique: Controverses, résistances, effets (pp. 281-316). Presses de Sciences Po.

Howlett, M. (2014b). From the 'old' to the 'new' policy design: Design thinking beyond markets and collaborative governance. Policy Sciences, 47(3), 187-207.

Howlett, M. (2018a). The context and components of policy design: Governance modes and policy regimes. In M. Howlett \& I. Mukherjee (Eds.), Routledge Handbook of Policy Design (pp. 20-33). Routledge.

Howlett, M. (2018b). The criteria for effective policy design: Character and context in policy instrument choice. Journal of Asian Public Policy, 11(3), 245-266.

Howlett, M. (2018c). Aligning policy tools and their targets: Nudging and utility maximization in policy design. In M. Howlett \& I. Mukherjee (Eds.), Routledge handbook of policy design (pp. 106-121). Routledge.

Howlett, M. (2019). The policy design primer: Choosing the right tools for the job. Routledge.

Howlett, M., \& Cashore, B. (2009). The dependent variable problem in the study of policy change: Understanding policy change as a methodological problem. Journal of Comparative Policy Analysis: Research and Practice, 11(1), 33-46.

Howlett, M., \& Mukherjee, I. (2018a). Introduction: The importance of policy design: Effective processes, tools and outcomes. In M. Howlett \& I. Mukherjee (Eds.), Routledge Handbook of Policy Design (pp. 13-19). Routledge.

Howlett, M., \& Mukherjee, I. (Eds.). (2018b). Routledge handbook of policy design. Routledge. https://doi. org/10.4324/9781351252928.

Howlett, M., Mukherjee, I., \& Rayner, J. (2018). Understanding policy designs over time: Layering, stretching, patching and packaging. In M. Howlett \& I. Mukherjee (Eds.), Routledge handbook of policy design (pp. 136-144). Routledge.

Howlett, M., Mukherjee, I., \& Woo, J. J. (2015). From tools to toolkits in policy design studies: The new design orientation towards policy formulation research. Policy and Politics, 43(2), 291-311.

Howlett, M., \& Rayner, J. (2013). Patching vs packaging in policy formulation: Assessing policy portfolio design. Politics and Governance, 1(2), 170-182.

Howlett, M., \& Rayner, J. (2018). Coherence, congruence and consistency in policy mixes. In M. Howlett \& I. Mukherjee (Eds.), Routledge handbook of policy design (pp. 389-403). Routledge.

Hull, A. (2005). Integrated transport planning in the UK: From concept to reality. Journal of Transport Geography, 13(4), 318-328.

Hull, A. (2010). Transport matters: integrated approaches to planning city-regions. Routledge. https://doi. org/10.4324/9780203938782 
Jordan, A., Wurzel, R. K. W., \& Zito, A. (2005). The rise of 'new' policy instruments in comparative perspective: Has governance eclipsed government? Political Studies, 53(3), 477-496.

Kern, F., \& Howlett, M. (2009). Implementing transition management as policy reforms: A case study of the Dutch energy sector. Policy Sciences, 42(4), 391.

Kern, F., Kivimaa, P., \& Martiskainen, M. (2017). Policy packaging or policy patching? The development of complex energy efficiency policy mixes. Energy Research and Social Science, 23, 11-25.

Marsden, G., \& Reardon, L. (2017). Questions of governance: Rethinking the study of transportation policy. Transportation Research Part a: Policy and Practice, 101, 238-251.

Mastop, H., \& Faludi, A. (1997). Evaluation of strategic plans: The performance principle. Environment and Planning $b$ : Planning and Design, 24(6), 815-832.

Mu, R., \& de Jong, M. (2016). A network governance approach to transit-oriented development: Integrating urban transport and land use policies in Urumqi, China. Transport Policy, 52, 55-63.

Mukherjee, I., \& Bali, A. S. (2018). Capacities and customization in policy design. In M. Howlett \& I. Mukherjee (Eds.), Routledge handbook of policy design (pp. 359-372). Routledge.

Mukherjee, I., \& Bali, A. S. (2019). Policy effectiveness and capacity: Two sides of the design coin. Policy Design and Practice, 2(2), 103-114.

Mukherjee, I., \& Howlett, M. (2018). Gauging effectiveness in policy designs. In M. Howlett \& I. Mukherjee (Eds.), Routledge handbook of policy design (pp. 375-388). Routledge.

Owens, S. (1995). From 'predict and provide' to 'predict and prevent'? Pricing and planning in transport policy. Transport Policy, 2(1), 43-49.

Peters, B. G. (2018). Policy problems and policy design. Edward Elgar Publishing.

Peters, B. G., Capano, G., Howlett, M., Mukherjee, I., Chou, M.-H., \& Ravinet, P. (2018). Designing for policy effectiveness: Defining and understanding a concept. Cambridge University Press, Cambridge. https://doi.org/10.1017/9781108555081

Polit, D. F., \& Beck, C. T. (2010). Generalization in quantitative and qualitative research: Myths and strategies. International Journal of Nursing Studies, 47(11), 1451-1458.

Potter, S., \& Skinner, M. J. (2000). On transport integration: A contribution to better understanding. Futures, 32(3), 275-287.

Ragin, C. C. (2009). Redesigning social inquiry: Fuzzy sets and beyond. University of Chicago Press.

Rayner, J., \& Howlett, M. (2009). Conclusion: Governance arrangements and policy capacity for policy integration. Policy and Society, 28(2), 165-172.

Rayner, J., Howlett, M., \& Wellstead, A. (2017). Policy mixes and their alignment over time: Patching and stretching in the oil sands reclamation regime in Alberta, Canada. Environmental Policy and Governance, 27(5), 472-483.

Reichardt, K., \& Rogge, K. (2016). How the policy mix impacts innovation: Findings from company case studies on offshore wind in Germany. Environmental Innovation and Societal Transitions, 18, $62-81$.

Rihoux, B., Álamos-Concha, P., Bol, D., Marx, A., \& Rezsöhazy, I. (2013). From niche to mainstream method? A comprehensive mapping of QCA applications in journal articles from 1984 to 2011. Political Research Quarterly, 66(1), 175-184.

Rihoux, B., \& Ragin, C. C. (2009). Configurational comparative methods: qualitative comparative analysis (QCA) and related techniques. SAGE Publications Inc. https://doi.org/10.4135/9781452226569

Rihoux, B., Rezsöhazy, I., \& Bol, D. (2011). Qualitative comparative analysis (QCA) in public policy analysis: An extensive review. German Policy Studies, 7(3), 9-82.

del Río, P. (2014). On evaluating success in complex policy mixes: The case of renewable energy support schemes. Policy Sciences, 47(3), 267-287.

Rogge, K. S., Kern, F., \& Howlett, M. (2017). Conceptual and empirical advances in analysing policy mixes for energy transitions. Energy Research and Social Science, 33, 1-10.

Rogge, K. S., \& Reichardt, K. (2016). Policy mixes for sustainability transitions: An extended concept and framework for analysis. Research Policy, 45(8), 1620-1635.

Rogge, K. S., \& Schleich, J. (2018). Do policy mix characteristics matter for low-carbon innovation? A survey-based exploration of renewable power generation technologies in Germany. Research Policy, 47(9), 1639-1654.

Schmidt, T. S., \& Sewerin, S. (2018). Measuring the temporal dynamics of policy mixes-An empirical analysis of renewable energy policy mixes' balance and design features in nine countries. Research Policy. https://doi.org/10.1016/j.respol.2018.03.012

Schneider, C. Q., \& Wagemann, C. (2012). Set-theoretic methods for the social sciences: A guide to qualitative comparative analysis. Cambridge University Press.

Straatemeier, T. (2019). Joint accessibility design: A framework to improve integrated transport and land use strategy making. Universiteit van Amsterdam. 
Thomann, E. (2018). 'Donate your organs, donate life!' Explicitness in policy instruments. Policy Sciences, 51(4), 433-456.

Tinbergen, J. (1952). On the theory of economic policy. North-Holland Publishing Company.

Trein, P., Meyer, I., \& Maggetti, M. (2019). The integration and coordination of public policies: A systematic comparative review. Journal of Comparative Policy Analysis: Research and Practice, 21(4), 332-349.

UN-Habitat. (2013). Planning and design for sustainable urban mobility: Global report on human settlements 2013. Routledge.

Verweij, S., \& Trell, E.-M. (2019). "Qualitative comparative analysis (QCA) in spatial planning research and related disciplines: A systematic literature review of applications. Journal of Planning Literature, 34(3), 300-317.

van Wee, B., Annema, J.A., \& Banister, D. (2013). The transport system and transport policy: an introduction. Edward Elgar.

van Geet, M. T., Lenferink, S., Arts, J., \& Leendertse, W. (2019a). Understanding the ongoing struggle for land use and transport integration: Institutional incongruence in the Dutch national planning process. Transport Policy, 73, 84-100.

van Geet, M. T., Lenferink, S., \& Leendertse, W. (2019b). Policy design dynamics: Fitting goals and instruments in transport infrastructure planning in the Netherlands. Policy Design and Practice, 2(4), 324-358.

van Geet, M. T., Lenferink, S., Busscher, T., \& Arts, J. (2021). Finding the right tools for the job: Instrument mixes for land use and transport integration in the Netherlands. Journal of Transport and Land Use, 14(1), 125-149.

Wegener, M., \& Fürst, F. (1999). Land-use transport interaction: State of the art, berichte aus dem institut für raumplaning 46. Universität Dortmund - Fakultät Raumplanung.

Yin, R. K. (2013). Validity and generalization in future case study evaluations. Evaluation, 19(3), 321-332.

Publisher's Note Springer Nature remains neutral with regard to jurisdictional claims in published maps and institutional affiliations. 